\title{
Arthur Jeffery ve Kur'ân Çalışmaları Üzerine
}

\section{Mesut OKUMUŞ}

Yrd. Doç.. Dr, Gazi Üniversitesi Çorum Ilâhiyat Fakültesi

On Arthur Jeffery and His Qur'anic Studies. Arthur Jeffery is a famous philologist and a minister of the Methodist Church. At the begining of his carrier, he performed some Biblical studies, but then, most of his works concentrated on the Islamic sciences, especially the Qur'an and its variant readings. Collaborating with some German researchers, he tried to collect all variant readings of the Qur'an in order to publish it as a complete text with a critical apparatus. However their attemp didn't succeed. In this article we described Qur'anic studies of Jeffery and his thoughts on the Prophet, the Qur'an and the variant readings. Also we summarized evaluations of some muslim and western scholars about Jeffery's studies and thoughts.

Key Words: Orientalism, Jeffery, Qur'an, textual critisism, variant readings

\section{Giriş}

Batı dünyasında İslâm dini ve onun en temel kaynağı olan Kur'ân'a duyulan ilginin çok eskilere dayandığı bilinmektedir. Bazı araştırmacılar son Ilâhî dinin kutsal kitabı olan Kur'ân üzerine yapılan ilk oryantalistik 
çalışmaların miladi XII. asrın ortalarında Kur'ân'ın Latince'ye çevrilmesiyle başladığını ancak gerçek anlamda modern oryantalizmin Fransız İhtilali'nden sonra ortaya çıktığını kabul etmektedirler. Bilimsel anlamda Kur'ân üzerinde odaklanan oryantalistik çabaların aradan geçen uzun tarihî süreç içerisinde kendine özgü farklı niyet ve hedefleri, bazı ilginç özellik ve nitelikleri olmuştur. Sömürgeciliğin yoğun olarak yaşandığı dönemlerde müstemlekeciler için bir keşif kolu ve ileri karakol olma; sömürgecilere danışmanlık yapma gibi bir işlevi yerine getiren oryantalizm ', sömürgeciliğin sona erdiği dönemlerde ulaşmak istediği amaçlara ilgi ve yönelişlerinde taktik değişiklikler yaparak varmaya çalışmak gibi ilginç özellikler sergilemiştir. Bütün oryantalistleri art niyetli olarak betimlemenin doğru olmadığı gerçeğini kabul etmekle beraber, bunların büyük bir kısmının genelde doğu özelde Müslümanları tanımaktan öte tanımlamaya çalıştıkları da bu gün kabul edilen bir realite haline gelmiştir. Bu incelemede oryantalistik Kur'ân çalışmaları içerisinde önemli bir yeri olduğu halde ülkemizde hakkında müstakil bir inceleme yapılmamış olan Arthur Jeffery'nin hayatı, Kur'ân ilimlerine dair yaptı̆̆g çalışmalar, Kur'ân ilimleri konusundaki temel görüşleri, yaptığı çalışmaların karakteristik özellikleri üzerinde durarak bunlara yönelik gerek doğu gerekse batılı araştırmacılar tarafından yapılan bazı değerlendirme ve eleştirilere yer vermeye çalışılacaktır.

\section{a- Hayatı}

Arthur Jeffery, sömürgecilik sonrası döneme ait aslen Avusturalya doğumlu olup sonradan Amerika'ya yerleşmiş olan müsteşriklerden birisidir. Avusturalya'nın Melbourne kentinde 1893 yılında doğan müsteşrik, ilk ve orta tahsilinden sonra üniversite eğitimini Melbourne Üniversitesi'nde almıştır. Edebiyat Fakültesi Diploması (B.A.1918), Master of Arts (M.A.1920) ve Teoloji Fakültesi diploması (B.Th.1926) aldıktan sonra mezun olduğu üniversitede hizmet vermeğe başlamıştır. ${ }^{2}$

Birinci Dünya Savaşı esnasında askerî hizmet talebi reddedilen Jeffery, Hindistan'da bulunan ve bir misyoner okulu olan Madras Christian College'de bir süreliğine öğretmen olarak hizmet verme imkanı bulmuştur. Ögrencilik yıllarından itibaren filolojiye ilgi duyan Jeffery, Hindistan'daki hizmeti esnasında eğitim-öğretim faaliyetine ilaveten doğu dillerine yönelik

1. Said Edward, Oryantalizm, Sömürgeciliğin Keşif Kolu, \&. S. Ayaz, Pınar Y. Ist, 1989. s.16-17.

2. Badeau S. John, "Arthur Jeffery-A Tribute", The Muslim World (MW), 50 (1960) s.5051 . 
lenguistic ve filolojik ilgisini devam ettirmiş, bir çok yerel dil alanında master yapma imkanı bulmuştur. Hindistan'da bulunan Madras Christian College'deki hizmeti esnasında Misır'a davet edilen A. Jeffery, 1921 yılından itibaren Kahire'de Amerikan Üniversitesi'nin yeni kurulan School of Oriental Studies bölümünde hizmet vermeğe başlamıştır.

School of Oriental Studies, önceleri Amerikan misyonuna misyoner adaylar yetiştiren ve eğitimi akademik düzeyde olmayan Language Study Center adıyla hizmet vermekteyken, 1921 yılından itibaren alanı genişletilerek School of Oriental Studies'e dönüştürülmüştür. Müsteşriklerce Müslüman dünya ile Batı arasında bir 'anlama köprüsü' olması amacıyla kurulduğu ifade edilen Amerikan Üniversitesi'nin söz konusu departmanı, aralannda Dr. Samuel Zwemer, Dr. Earl E. Elder ve Canon Temple Gairdner'in de bulunduğu bir çok ileri gelen müsteşriğe bünyesinde hizmet verme imkanı sağlamıştır. Kahire'deki görevine başlayıncaya kadar asıl ilgisi ve uzmanlık alanı Kitab-ı Mukaddes'le ilgili çalışmalar üzerine olan Jeffery, Kahire'ye geçişinden sonra Kur'ân çalışmaları üzerine yoğunlaşmıştır. Arkadaşlanının belirttiğine göre Arthur Jeffery, doktorasını 1929 'da Edinburgh Úniversitesi'nden özel onurla almıştır. Bunu aynı kurumdan 1938'de pekiyi derece ile almış olduğu edebiyat doktorası izlemiştir. ${ }^{3}$

1923 yllında Kahire Amerikan Üniversitesi rektörünün sekreteri olan Elsie Gordon Walker'la evlenen Jeffery, 1938 yılında Kahire'deki eğitim kurumundan ayrılarak Amerika'ya geçmiş ve Columbia Üniversitesi'nin (New York) Yakın Doğu ve Ortadoğu Dilleri kürsüsünde görev yapmaya başlamıştır. ${ }^{4}$ Bundan sonraki akademik ve ilmi kariyerini bu üniversitede sürdürmüş, bir süre Union Theological Seminary'de Samî Diller bölümünde yardımcı profesörlük yapmış, ayrıca 1946-1947 yıllan arasında Kudüs Amerikan School of Oriental Research'te bir yıllığına misafir profesör olarak hizmet vermiştir..$^{5}$

Vefatı dolayısıyla yayımlanan Armağan'da Eric F.F. Bishop, Jeffery'nin on dokuz dil bildiğine, öğrendiği diller arasında en zor olarak Arapça'yı bulduğuna dair bir söylenti bulunduğunu aktarmaktadır. Jeffery'nin çeşitli diller konusundaki geniş bilgi birikimine dair bu söylentinin doğru olabileceğini çünkü The Forein Vocabulary of the Qur'an adlı eserinin

3. Badeau, "Arthur Jeffery-A Tribute", $M W, 50$ (1960) s.50; Aynca ölüm haberi üzerine $M W$ dergisinde yer alan editör açıklaması için bkz: $M W, 49,(1959)$, s.348.

4. Badeau, "Arthur Jeffery-A Tribute", s.51.

5. Jeffery'nin, "The Textual History of the Qur'an" başlıklı makalesinin sonunda yer alan tanitım yazısı, JMES I (1947), Part II, s.49. 
indeksinde zikredilen çeşitli dillere ait kelimeler listesinin de bunu ispatladığını vurgulamaktadır .

Jeffery, New York Columbia Üniversitesi Samî Diller bölümünde Arapça profesörü olarak görev yaptığı dönemde 2 Ağustos 1959 tarihinde Nova Scotia'da (Kanada) tatilini geçirirken vefat etmiştir.?

\section{b-Hristiyanî Duyarlılığı}

Arkadaşlan tarafından Metodist Kilisesi'ne mensup bir papaz (minister) olduğu ve hayatını misyonerlik davasına adadığı belirtilen Jeffery, bu alandaki çabaları dolayısıyla meslektaşlannca misyoner etkinlik alanında derin Hristiyanî ilginin bir örneği olarak gösterilmektedir ${ }^{8}$.

Columbia Üniversitesi'nden kendisini tanıyan ve yirmi yıl aynı çatı altında beraber hizmet verme ve onunla komşu olma imkanı bulduğunu ifade eden meslektaşı Frederick C. Grant, Jeffery'nin dinî yaşantısının kutsal literatüre yönelik akademik çalışmalanı ötesinde bir bilgin, öğretmen, yazar, konferansçı ve komşu olarak sade, samimi ve sıcak olduğunu, her sabah 8.30, Pazar günleri de genellikle saat 11 'de Union Seminary'deki küçük kilisede verdiği içli vaazlardan herkesin son derece etkilendiğini belirtmektedir. ${ }^{9}$

Arthur Jeffery'nin, Hristiyanlık konusunda oldukça duyarlı olduğu eserlerinden de anlaşılmaktadır. Çalışmalarına, özellikle neşredilen makalelerine bakıldığında Hristiyanlarla Müslümanlar arasındaki ilişkilere büyük önem verdiği ve özellikle İslâm dünyasında yayımlanan Hristiyanlık karşıtı yayınlarla ilgili bilgiler derlediği ve bunlara yönelik değerlendirmeler yaptığı görülmektedir.

Hristiyanlık konusunda duyarlılığı ile dikkati çeken Jeffery, İslâm dünyasında ortaya çıkan son dönemlerdeki eklektik dinî hareketlerde Hristiyan düşüncesinin güçlü bir etkisi olduğunu düşünmektedir. Yine yazdığı bir makalede İslâm âlemindeki Hristiyanlıkla ilgili faaliyetlere değinen Jeffery, Müslümanlar arasındaki Hristiyan misyonunda büyük umut olduğunu belirtmekte ve şayet İslâm âlemindeki Hristiyan misyonlan özellikle eğitimli insanların düşüncelerini Hristiyan idealleri ve Hristiyan ruhu ile mayalandırabilirse, Hristiyanlığın yaşam gücünün kaçınılmaz olarak Müslümanların Hristiyanlıkla ilgili imajlarını dönüştüreceğini ileri

6. Bishop, F.F. Eric, "Arthur Jeffery-A Tribute", $M W, 50$ (1960) s.51.

7. Schacht Joseph, A Reader on Islam (Introduction), Mouton \& Co:: The Hague, 1962, s. 10; ayrıca ölüm haberi üzerine The Muslim World'da yer alan editör açıklaması için bkz.: $M W, 49(1959)$, s.348.

8. Badcau, "Arthur Jeffery-A Tribute", s.51.

9. Grant, Frederick C, "Arthur Jeffery-A Tribute", s.53. 
sürmektedir. Ona göre bu çabalann meyvesi, İslâm dünyasının tamamen Batı kiliselerinde gördüğümüz gibi organize bir şekilde Hristiyanlık düşüncesine girmesi şeklinde olmayacaktır. Daha doğal olan sonuç, İslâm dünyasında dinî yaşam şekillerini bildiğimiz organize kilise hayatından geniş oranda farklı olarak ifade eden bir Hristiyan Kilisesi'nin gelişmesidir. ${ }^{10}$

Jeffery, Hindistan'da ortaya çıan ve Müslümanlığı müjdelediği söylenen yeni bir Tevrat'ın yayımlanması ile ilgili bir inceleme ve değerlendirme yaptıktan sonra dünyanın değişik bölgelerinde Hristiyanlığı yaymaya çalışan misyonlar için şu uyarıda bulunmaktadır:

"Örnek olmast açısından kitabın girişi ve ilk beş suresinin bir çevirisini buraya ekliyoruz. Islâm dünyasının ̧̧eşitli bölgelerindeki misyonerler Hristiyanlık karşıtı propaganda amaciyla kullanılmakta olan bu ve benzeri yayınlar hakkında bilgi sahibi olup dikkatli olsunlar. $" 11$

\section{c- Matbu Eser ve Çalışmaları}

Arthur Jeffery, Kur'ân'ın metinleşme tarihi ve kıraâtleri konusunda yayımlanmış çok sayıdaki çalışmasıyla dikkati çekmektedir. Bunlar arasında kendinin yazdığı müstakil çalışmalann yanı sıra tahkik ve notlandırmak suretiyle yayımlamış olduğu eserler de bulunmaktadır.

1- Kitâbu'l-Mesâhîf: Bu çalışma Ibn Ebi Davud'a (ö.316) ait Kitâbu'l Mesâhîf adı eserin Jeffery tarafından yapılan tahkikli neşri olup aşağıda adı geçen Materials isimli eserle birlikte neşredilmiştir (Mısır, 1355/1936).

2-Materials for the History of the Text of the Qur'an-The Old Codices, (Leiden, 1937). Yazarın Kur'ân'ın metinleşme tarihini ele alan ve çok sayıda sahabenin kişisel mushaflarında yer aldığı ileri sürülen kıraât farklılıklarını derlediği bir çalışmadır. Jeffery burada Kur'ân'ın metinleşme tarihi ile ilgili uzunca bir girişten sonra ${ }^{12}$ çeşitli tefsir, lugat ve edebî kaynaklardan derlediği Ibn Mes'ud, Ubey b. Ka'b, Hz. Ali, İbn Abbas, Ebu Musa, Hafsa, Enes b. Malik, Hz. Ömer, Zeyd b. Sabit, İbnu'z-Zübeyr, İbn 'Amr, Hz. Aişe, Sâlim, Ümmü Seleme ve Ubeyd b. Âmir gibi sahabe mushaflarındaki kıraât farklılıklarını nakletmektedir.

10. Jeffery, "Eclecticism in Islam", $M W, 12(1922)$ s.246-247.

11. Jeffery, "A Moslem Torah From India", $M W, 15$ (1929), s. 236.

12. Fazlur Rahman, Jeffery'nin bu escrini Kur'ân Tarihi konusunda bahse değer görmekte ancak bu kitabın okunurken dikkatli olunması gerektiğini vurgulamaktadır. Bkz: Fazlur Rahman, Ana Konularıyla Kur'ân, ç. A.Açıkgenç, Ank, 1996, s.33; İsmail Cerrahoğlu da, bu çalışmayı değerlendirirken onun Alman müsteşrik Bergstrasser'in çalıştığı sahada ve onun yolunda oluşunun bir işareti sayılabileceğini bclirtmektedir. Bkz. Cerrahoğlu İsmail, "Oryantalizm ve Batıda Kur'ân ve Kur'ân İlimleri Üzerine Araştırmalar", AÜIFD, 1989, c. XXXI, s.111. 
3- The Foreign Vocabulary of the Qur'an, (Baroda, 1938). Jeffery'nin bilinen en meşhur eseri olup doktora çalışmasıdır. Adından da anlaşıldığı üzere Kur'ân'da yer alan yabancı kelimeler konusunu ele almaktadır. Yazar 320 kadar yabancı kelimenin değişik dil ve kültürlerden Kur'ân’a geçtiğini iddia etmektedir. ${ }^{13}$

4- Index of Qur'anic Verses to The English Part of Materials for the History of the Text of the Qur'an (Leiden, 1951). Müellifin, Materials adlı eserine ek olarak yayımlanmıs, mushafların her birinde mevcut kıraât farklılıklarını sure tertibine göre gösteren geniş bir fihristtir.

5- Mukaddimetân fî Ulûmi'l-Kur'ân, (Misır, 1954). İbn Atiyye elEndelüsî'nin el-Muharrerü'l-vecîz'inin mukaddimesi ile yazarı bilinmeyen Kitabu'l-Mebâni li-nazmi'l-meânî adlı bir başka eserin mukaddimelerinin Jeffery tarafından bir giriş, notlandırma ve düzeltmeler ekleyerek yayımlanmış şeklidir. Jeffery çalışmayı, Alman asıllı müsteşrik Bergsträsser'e ithaf etmiştir. Ancak Jeffery bu ikinci eserin mukaddimesinin pek çok yerini tahrif ettiği ve önemli hatalar yaptığı gerekçesiyle eleştiriye uğramıştır. ${ }^{14}$

6- The Qur'an as Scripture, (New York, 1952). Bu çalışma yazarın The Muslim World dergisinde yayımlanan İslâm'daki metin doktirinini ele alan dört adet makalesine Kur'ân'ın metinleşme tarihini ele alan bir bölüm daha ekleyerek kitap haline getirdiği bir çalışmasıdır.

7- Islam, Muhammad and His Religion (New York, 1952).

8- The Qur'an-Selected Surahs: (New York, 1958). Yazarın Kur'ân'dan seçmiş olduğu bazı surelerin çevirilerini içeren eseridir.

13. D.S. Margoliouth, yayımladığı bir makalede bu eserdeki kelimelere bazı ilaveler yapmakta, bu çalışmanın Kur'ân'ın Yahudi ve Hristiyan kaynağı konusundaki oryantalistik tezleri bir kez daha desteklendiğini, yeni yaklaşımlara yol açtığını ileri sürmekte ve esere duyduğu hayranlığını dile getirmektedir. Bkz: D. S.Margoliouth, "Some Additions to Professor Jeffery's Foreign Vocabulary of the Qur'an", JRAS, 1939, s.60-61. Bu eserin $\mathrm{XX}$. Yüzyılda batıda Kur'ân hakkında yapılan araştırma ve incelemeler arasında zikre değer bir inceleme oldựunu belirten I. Cerrahoglu, çalışmanın Kur'ân'ın Ilâhî bir kitap olduğunu kabul etmeyip ona yabancı bir menşe aramaya kalkışanlar için iyi bir müracaat kitabı olduğunu belirtmektedir. Eserin daha ziyade geçmiş çalışmaları hülasa ettiğini bu arada bazı yeni görüşler de ortaya atığını belirtmektedir. Bkz. Cerrahoğlu, "Oryantalizm ve Batıda Kur'ân ve Kur'ân İlimleri Üzerine Araştırmalar", AÜIFD, 1989, c. XXXI, s.111.

14. Tallal Abdullah Melluş, Takvîmu cehdi'l müsteşrik Arthur Jeffery fî tahkîkihî li-mukaddimeti Kitâbi'l-Mebâni li-nazmi'l-me'âni (Yüksek lisans tezi, 1409/1989), Câmiatu İmam Muhammed b. Suûd el-Islâmiyye, s.10-24; Kurtuluş Rıza, "Arthur Jeffery", DIA, XXIIJ, $578^{\circ}$ den naklen. 
9- A Reader on Islam: (The Hague, 1962). İslâm dininin inanç ve amellerine dair Arapça metinlerden çeviri derlemesi olup neşredemediği bir çalışmadır. Vefatından sonra arkadaşlanı tarafından kısmi teknik düzenlemeler yapılmak suretiyle yayımlanmıştır.

\section{d-Yayımlanmış Makale ve Diğer Çalışmaları}

Arthur Jeffery'nin yukarıda anılan eserlerine ilave olarak, değişik dergi ve süreli yayınlarda neşredilmiş çok sayıda kitap tanıtımı ve değerlendirmesi, bireysel ve ortak çalışma şeklinde makalesi ve çevirileri bulunmaktadır. The Muslim World dergisi ve Pearson'un Index İslamicus'u, ayrıca kendi çalışmalarında verdiği bilgiler ve el-Müsteşrikun ${ }^{15}$ adlı eserlerden tesbit edebildiğimiz kadariyla -muhtelif ansiklopedilere yazmış olduğu maddelerle Biblical sahadaki incelemeleri hariç'16- Jeffery'nin Islamî sahada yayımlanmış bireysel ve ortak makaleleri ile yaptığı çevirilerin kronolojik listesi aşağıdaki şekildedir.

1. "Eclecticism in Islam", The MuslimWorld (MW),12 (1922) s. 230247.

2. "The Mystic Letters of The Qur'an", $M W, 14(1924)$ s.247-260.

3. "A Reference to The Ishtar-Cult in The Qur'an", AJSL, 41 (19241925) s.280-282.

4. "The Quest of Historical Muhammad", $M W, 16(1926)$ s.327-348.

5. "The Anti-Chiristian Muslim Press", $M W, 16$ (1926) s.425-427.

6. "The Anti-Christian Muslem Press", $M W, 17$ (1927) s.428-430.

7. "Anti-Christian Literature", $M W, 17$ (1927) s.216-219.

8. "A Moslem Torah From India", $M W, 15$ (1929) s.232-239.

9. "A Collection of Anti-Christian Books and Pamphlets Found in Actual Use Among the Mohammedans of Cairo", $M W, 15$ (1929) s.26-37.

10. "Christians at Mecca", $M W, 19(1929)$ s.221-235.

11. "Was Muhammad a Prophet From His Infancy?", MW, 20 (1930) s.226-234.

12. "Current Topics", $M W, 22$ (1932) s.77-83.

13. "Su Due Raconti Traduzuoni Musulmane İnglosi del Corano", Oriente Moderne (OM), 12 (1932) s.109-116.

14- "The Supressed Qur'an Commentary of Muhaemd Ebu Zaid", Der Islam XX (1932), s.301-308.

15. el-Akikî, Necip, el-Müsteşrikûn, Daru'l Maarif, Beyrut, III, 158-159.

16. Jeffery'nin Biblical çalışmalan için bkz. Journal of Biblical Studies, 79 (Mart 1960), I, VIII-IX; Chaudhary, Muhammed, "Orientalism on Variant Readings of the Qur'an: The Case of Arthur Jeffery", AJISS, c.XII, S.2 (1985) s.170. 
15. "Il Modernismo Musulmano dell İndiano "Sir" Mohammad Iqbal", (OM), 14 (1934), s.505-513.

16. "Progress in The Study of Qur'an Text", $M W, 25(1935)$ s.4-16.

17. "Had Muhammad a Scripture Teacher", (From the Pyramids to Paul içinde), ed. by Lewis Gaston Leary, (New york: Thomas Nelson and Sons, 1935) s. 95-115.

18. "The Qur'an Readings of Zaid b. Ali", Rivista degli Studi Orientali (RSO), 16(1936) s.249-289.

19. "Marginalia to Bergstrasser's Edition of Ibn Halawaih", Islamica Schlussheft (=AKM 23VI), 1938, s.130-155.

20. "Abu Ubaid on The Verses Missing From Qur'an", MW, 28 (1938) s.61-65.

21. "The Prophet of Islam", $M W, 28$ (1938) s.180-186.

22. "A Variant Text of The Fatiha", $M W, 29$ (1939) s.158-162.

23. "Yusuf Ali's Translation of The Qur'an", $M W, 30$ (1940) s. 5466.

24. "Further Qur'an Readings of Zaid b. Ali", RSO, 18 (1940) s.218236.

25. "David Samuel Margoliouth", $M W, 30$ (1940) s.295-298.

26. "The Orthography of the Samarkand Qur'an Codex:", Journal of American Oriantal Society (JAOS), 62 (1942) s.175-195, I Mendelsohn ile ortaklaşa yayımlamış olduğu bir makaledir.

27. "The Political Importance of Islam", Journal of Near Eastern Studies (JNES), I (1942) s.383-395.

28. "Gregory of Tathew's "Contra Mohammedanos", MW, 32 (1942) s.219-235 26.

29. "Present-day Movements in Islam", $M W, 33(1943)$ s.165-186.

30. "Ghevond's Text of The Correspondence Between Umar II and Leo III", Harvard Theolojical Rewiev, 37 (1944) s.269-332.

31. "Miguel Asin", $M W, 35$ (1945), s.273-280.

32. "Christianity in South Arabia", MW, 36 (1946) pp. 193-216 (Reprinted from Anglican Theolojical Review, Vol. XVII, No. 3, July, 1945 s.272-280.

33. "The Textual History of The Qur'an", Journal of Middle East Society (JMES), I (1947) Part II, s. 35-49.

34. "The Qur'an Reading of Ibn Miqsam", Goldziher Mem. Vol 1 (1948) s.1-38.

35. "The Qur'an as Scripture", $M W, 40$ (1950) s.41-55;106-134;185206; 257-275. Derleyerek kitap haline getirdiği makaleleridir. 
36. "Al Biruni's Contribution to The Comparative Religion", Al-Biruni Commem. Vol. 1951, s.119-123.

37. "The Present Status of Qur'anic Studies", Report on Current Research, Middle East Institue, (Spring, 1957), s.1-16.

38. "Ibn al-A'rabi's Shajarat el Kawn", Studıa Islamica, IX (1958) s.113-160 İbn Arabi’nin eserini notlandırarak çevirmiştir

39."Ibn el-A'rabi", Studıa Islamica, (1959) s.1-11.

\section{e- Hz. Peygamber, Kur’ân ve Kur'ân Kıraâtlerine Dair Görüşleri}

\section{1-Hz. Muhammed'e Bakışı}

Bir müsteşriğin Kur'ân'a bakışını belirleyen ve onu Müslüman bir araştırmacıdan farklı kılan en önemli unsurun $\mathrm{Hz}$. Peygamber'e ve bunun sonucu olarak da Kur'ân'a olan bakışında düğümlendiğini söyleyebiliriz. Son İlâhî dinin kutsal kitabı olan Kur'ân'a bakışı belirleyen de bir anlamda bu dinin peygamberine bakıştır. Hz. Muhammed'in bir peygamber olmadı kabul edilince doğal olarak Kur'ân'ın İlâhîliği de reddedilecek ve bu temel anlayış farklılığı, elde edilen bulguların değerlendirilmesini de etkileyecektir. Araştırma ve incelemede elde edilen veriler çok farklı değerlendirme ve mülahazalara imkan verecektir. Tabii konumuz küçüklüğünden itibaren Hristiyanî eğitim almış ve misyoner okullarında çalışmış bir araştırmacı olunca bu farklı bakışın kaçınılmaz bir sonuç olacağı ortadadır.

Bilindiği gibi oryantalizmin tarihi çok eskilere hatta Haçlı Seferlerinin başladığı dönemlere veya Endülüs'e kadar geri götürülebilirse de modern oryantalizmin Fransız İhtilali sonrasında başladığı söylenebilir. Aradan geçen bir kaç asır içerisinde oryantalizmin hem yaklaşımlarında hem de yöntemlerinde bir takım değişikler olmuştur. Ancak eski oryantalistik yaklaşımlarla yenileri arasında farklılıklar bulunsa da bunların iki temel noktada birleştiklerini söyleyebiliriz: Klasik oryantalizmden farklı olarak yeni metotlarla tetkik ve inceleme yapan çağdaş oryantalistler, peşin hükümlerden ve hissiyattan uzak kaldıklarını iddia ediyorlarsa da ön yargılarını belirli küçük bir noktada da olsa belirtmekten kendilerini alamiyorlar. Genellikle eserlerinde Hz.Peygamber'i ve Kur'ân'ı metheder gibi görünseler de, eserlerinin ana fikrini ifade eden bir veya bir kaç cümlecik içerisinde İslâm'ın temelini sarsacak ve inanç sistemini yıkacak fikirlerle karşılaşmamak mümkün değildir. Yeni metotlarla çalıştığını söyleyen pek çok oryantalistin eserinde iki mesele gizli ve aşikar olarak daima kendini göstermektedir. Bunlardan biri ' $H z$. Muhammed'in 
nübüvvetinin sihhati' diğeri de 'Kur'ân'ın menşei ve onun bir vahiy mahsulü olup olmadı ğı meselesi'dir. ${ }^{17}$

Bugün batıda Kilise eğitimi görmüş bir çok kimse, Kur'ân-1 Kerim'in Allah'ın bir vahyi olmadı̆̆ına, Hz. Muhammed'in Allah elçisi olarak gönderilmediğine inanmaktadırlar. Çünkü Hristiyanlığın en üst ve en son din olduğuna, onun dışında kurtuluşun mümkün olmadığına ve dolayısıyla ondan sonra başka bir dinin gelemeyeceğine kani olmuşlardır.

Hristiyan ilim adamlarından İslâm'ı gerçek şekliyle anlatan eserler yazmalarını beklemek gerçekten saflık olacaktır. Zira hepsi de bu yanlış anlayışın bir sonucu olarak İslâm dininin Ilâhî bir din olmadığı, aksine onun Yahudi ve Hristiyanlardan istifade etmek suretiyle bizzat $\mathrm{Hz}$. Muhammed tarafından kurulduğu hususunda görü̧̧ birliğine varmış bulunmaktadırlar. Yine bu araştırmacılann kendi dinlerine tatbik edilmesine şiddetle karşı çıktıklan, tatbik edenleri şiddetle kınadıklan ve hatta sahte ilim yapmakla itham ettikleri rasyonalistlerin 'aşırı tenkit' (derin tenkit) metodunu İslâm'a tatbik etme hususunda görüş birliğine vardıklarını görüyoruz.18

Yukanda konuyla ilgili daha önce yapılan çalışmalardan özetlemeler yaparak değinmeye çalıştığımız temel ayırım ve ortak yaklaşımın A. Jeffery ve çalışmaları, onun Peygambere bakışı için de geçerli olduğunu söyleyebiliriz. Arthur Jeffery, eserlerinde ve makalelerinde $\mathrm{Hz}$. Muhammed'i değerlendirirken yerine göre gerek Müslümanların gerekse müsteşriklerin sunmaya çalıştıklanı farklı peygamber tasavvurlarına eleştiriler yönelterek kendi tezlerini açıklama yolunu seçse de, $\mathrm{Hz}$. Peygamber ve Kur'ân'a yönelik değerlendirmelerinde yukanda anahatlarını belirlemeye çalıştığımız çizgide yer almaktadır.

$\mathrm{Hz}$. Peygamberle ilgili değerlendirmelerinde Jeffery, onun küçüklüğünden beri şirke bulaşmadığı ve İlâhî koruma altında tutulduğu, atalarının putlanna tapmadığı şeklinde bazı Müslümanların sahip oldukları anlayışın sonradan ortaya çıkan liderlerin idealize edilmesi ve efsaneleştirilmesi olgusunun bir sonucu olduğunu ileri sürmektedir. Müslümanların Peygamberleriyle ilgili bu anlayışlarını İsa ve Buda efsanelerine dayanarak yarattıklarını ileri sürmektedir. İddialarını delillendirme bağlamında, oğlunun adının Abdi Menaf olması, üç kızının da putperestlerle evli oluşu, içi putlarla dolu olan Ka'be'nin tamiri sırasında Haceru'l Esved' in yerine konulması için görev alması, Ahmed b. Hanbel'den

17. Cerrahoğlu, "Oryantalizm ve Batıda Kur'ân ve Kur'ân Ilimleri Üzerine Araştırmalar", s.115.

18. Akdemir. Salih, "Müsteşriklerin Kur'ân-ı Kerim ve Hz. Muhammed'e (s.) Yaklaşımları", $A \ddot{U} I F D$, Özel Say1, 1988, c.XXXI, s.189. 
gelen bir rivayete göre gençliğinde yatmadan önce Lat ve Uzza'nın adını anması, yine Müsned'e dayanarak artık putlar için kesilen hayvanların etinden yemeyeceği, Yakut'un Mucem'inde yer alan peygamberin kendi ağzından nakille gençliğinde Uzza'ya bir koyun kurban edişini zikretmektedir. ${ }^{19}$ Zikredilen verilere dayanarak $\mathrm{Hz}$. Peygamber'in küçüklüğünden itibaren putlara tapmayıp $\mathrm{Hz}$. İbrahim'in hanif olarak nitelenen dinine mensup olduğu şeklindeki Müslüman inanışının aksine, peygamberin müşriklerin dinine tâbi olduğunu ileri sürmektedir. ${ }^{20} \mathrm{Bu}$ görüşünü delillendirirken Jeffery'nin yerine göre en zayıf rivayetleri dahi iddiaları için malzeme olarak kullanabilmesi, en sahih ve sağlam olan Kur'ân ayetlerini görmezden gelebilmesi dikkat çekicidir.

Peygamber konusunda oryantalistlerin geçmişte yapmış oldukları saralı, mistik, inmeli-felçli, saplantılı şeklindeki görüş ve değerlendirmelerin de doğru olmadığını belirtmekte ve bu tür yaklaşımları eleştiriye tâbi tutmaktadir. Jeffery, Hz. Muhamed'le ilgili olarak Richard Bell'in ortaya attığı 'devlet adamı' tezine meylederek onun yaklaşımının daha doğru olduğunu, değerlendirmelerde bu tezin bir ipucu ve başlangıç noktası olarak alınabileceğini ileri sürmektedir. ${ }^{21}$

Jeffery, Hz. Muhammed'in tarihî bir realite olarak kabul edilmesini, hayatının efsanelerin bulanıklığından arındırılmasını, toplumsal bir lider olarak görülmesini, dinler tarihindeki gerçek yerine oturtulması ve dolayısıyla ona göre değerlendirilmesini istemektedir. ${ }^{22} \mathrm{~Hz}$. Peygamber'i mistik ya da dinî bir reformcu olarak görmekle beraber, daha çok tarihin kritik bir noktasında biraz ilkel insanlarnn arasındaki politik problemlerle yüzleşen bir insan olarak değerlendirilmesi gerektiğini ileri sürmektedir. ${ }^{23}$ Ona göre $\mathrm{Hz}$. Muhammed, gençliğinde yüksek medeniyetlerden özellikle büyüik Doğu Roma İmparatorluğu'nun dininden etkilenmiş, Araplan da böyle bir dinden yararlandırmaya çalışmış ve onlara bu medeniyetin bazı ölçülerini kazandırmayı düşünmüşşür. ${ }^{24}$

Bir devlet adamı ve dinî bir reformcu olarak gördüğü peygamberin hayatında ve nübüvvet tecrübesinde zamanla bir değişiklik ve dönüşümün yaşandığını ileri sürmektedir. Hz. Peygamber'in yaşadığı ilk vahiy tecrübesi

19. Jeffery, "Was Muhammad a Prophet From His Infancy?", $M W, 20(1930)$ s. 228-233.

20. Yakut el-Hamevî, Mu'cemu'l Buldan, ed.Wüstenfeld, III, 664. Jeffery, "Was Muhammad a Prophet From His Infancy?", s. 233.

21. Jeffery, "The Quest of Historical Muhammad", $M W, 16(1926)$, s.348.

22. Jeffery, "Was Muhammad a Prophet From His Infancy?", $M W$, s. 234.

23. Jeffery, "Quest of the Historical Mohammed", s.338.

24. Jeffery, The Foreign Vocabulary of the Qur'an, s. 38. 
sonrasında Varaka b. Nevfel'e gitme hikayesini onun 'esinlenmeden' (inspiration) 'vahiy' (revelation) kavramına geçişinin bir delili saymaktadır. Ona göre Muhammed'in hayatındaki esinlenme çocukluk ve gençlik evresine ait bir olgu, vahiy düşüncesi ise Ehl-i Kitab'la temas kurduktan sonraki döneme ait bir gelişmedir. ${ }^{25}$

Arthur Jeffery, özellikle Medine döneminde Ehl-i Kitab'la kurduğu temas sonucunda $\mathrm{Hz}$. Muhammed'in yalnızca Kur'ân'ın teknik dinî terminolojisini Kitab-l Mukaddes geleneğinden almakla kalmadığını, İslâm'ın temel doktrinleri ve dinî uygulamalarını da oradan devşirdiğini belirtmektedir. ${ }^{26}$ İlk dönemlerde onun önceki peygamberlerden ve büyük dinlerden çok az bahsettiği daha sonra bilgisini artırarak Hristiyan ve Yahudi kaynaklardan aldığı dinî terimleri kullanmaya başladığını, dahası başlangıçta Hristiyan ve Yahudilerin ayrı dine mensup olduklarını bile bilmediğini ancak sonradan bunu öğrenince hemen dil ve söyleminde değişiklikler yaptığını ileri sürmektedir. ${ }^{27}$ Jeffery'e göre $\mathrm{Hz}$. Peygamber önceleri Ehl-i Kitab tarafından kabul göreceğini umarak iyi niyetle onlara yönelmiş, ancak reddedilince Tevrat ve İncil' in tahrif edildiğini iddia etmiş, Hz. İbrahim'e ve onun Hanif dinine uyduğunu ileri sürerek çağrı ve söyleminde taktik değişiklikler yapmıştır. ${ }^{28}$ Tabii bu taktik değişiklikler ona göre Muhammed'in eseri olan Kur'ân için de geçerlidir. Jeffery'ye göre Kur'ân'daki Ehl-i Kitab'a yönelik ayetler başlangıçta peygamberin önceki İlâhî kitaplarda vadedildiğini belirtilmekte ve onları İslâm'a çağırmaktadır. Ancak bu çağrı, onun beklentilerinin aksine Yahudi ve Hristiyanlar tarafından reddedilmiştir. Dolayısıyla zaman içinde Kur'ân'da, yaşanan tarihsel olayların sonucuna göre Ehl-i Kitab'ı düşman sayan ve $\mathrm{Hz}$. Muhammed'in $\mathrm{Hz}$.İbrahim'in dinine mensubiyetini vurgulayan ayetlerde dikkati çeken bir takım söylem değişiklikleri gerçekleşmiştir.

Sonuç olarak ona göre İslâm ve onun İlâhî kitabı Kur'ân, $\mathrm{Hz}$. Muhammed'in eseridir, bu eser başka kaynaklardan yararlanılarak meydana getirilmiştir. Peygamberin başlangıçta Ümeyye b. Ebi Salt, Müseyleme ve Hanifler gibi tek tanrılı inanç arayışlarına yönelik adımlan izlediğini, büyük oranda onun yolunu hazırlayanların artık tarihte ancak belli belirsiz bir şekilde seçilebilirken onun politik gücü kullanarak bir dünya figürü haline

25. Jeffery, "Qur'an as Scripture", MW, III. makale, s.195.

26. Jeffery, "Had Muhammad a Scripture Teacher", s.95; Jeffery. "Qur'an as Scripture", $M W$. I.makale, 53; III, 205; Patrick O'Hair Cate, Each Other's Scripture, New Hartford, May, 1974, s.248.

27. Jeffery, Quest of the Historical Mohammed, MW, 16 (1926), s.348.

28. Jeffery, "Qur'an as Scripture", MW. III.264-265. 
geldiğini belirtmektedir. ${ }^{29}$ Jeffery, yayımladığı bir makalesinde $\mathrm{Hz}$. Muhammed'in eklektik bir dinî sistem kurmada başarılı olduğunu kabul ederek, bazı müsteşriklerin konuyla ilgili görüşlerine yer vermekte, tarihî süreçte ve günümüzde Müslümanlar arasında bir çok dinî akım ve mezhebin ortaya çıktığını ifade etmektedir. Jeffery, eklektik bir din olduğunu iddia ettiği İslâmiyet'in kendine özgü bir yaşam gücü olduğunu kabul etse de, dışardan yeni yaşam kaynaklan ile işbirliği yapmadan bu yaşam gücünün artık bundan sonra kendini daha ötelere taşıyamayacağını ileri sürmektedir. ${ }^{30}$

Onun Hz. Peygamber'e ve İslâm'a yönelik bu bakışından sonra temel görüşlerinin ikinci önemli unsurunu oluşturan Kur'ân'a bakışına ve onun muhtevasına yönelik değerlendirmelerine geçebiliriz.

\section{2- Kur'ân'a Bakışı}

Bilindiği gibi Hz. Peygamber'e yönelik değerlendirmelerde olduğu gibi Kur'ân ve onun menşei konusundaki oryantalistik yaklaşımlarda da bir takım farklılıklar dikkati çekmektedir. Ancak bu oryantalistlerin görüşleri arasındaki bu farklılıklar Kur'ân'ın kaynağı ve menşeinin İlâhî olmadığı noktasında birleşmeye doğru giderken, ona bir takım beşen̂ kaynaklar bulmada ayrışma ve farklılaşma göstermektedirler. Bazı oryantalistler Kur'ân'ın kaynağını Yahudiliğe ve Tevrat'a dayandırmakta ve Peygamber'in Kuran'ı oradan devşirdiğini, Kur'ân'ın asıl kaynağının Yahudilik ve onların kutsal kitabı olduğunu iddia etmektedirler. Bu tez daha çok Yahudi asıllı oryantalistler için geçerli olan ve onların eserlerinde gözlenen bir yaklaşımdır. Oryantalistlerin bir kısmı ise Kur'ân'ın asıl kaynağının İncil olduğunu ileri sürmekte $\mathrm{Hz}$. Peygamber'in onu İncil'den etkilenerek oluşturduğunu iddia etmektedirler. Bunlara göre de Muhammed, Kur'ân'1 İncil'den ve Hristiyanlık'tan etkilenerek oluşturmuştur. Bazı oryantalistler bu iki yaklaşımı birleştirerek Kur'ân üzerinde hem Tevrat hem de Íncil'in etkileri olduğunu ve onun asıl kaynağının bu iki kitaba dayandığını ileri sürmektedirler. Hatta bu tezlere ilaveten Kur'ân'da putperest tesirleri görenler olduğu gibi Kur'ân araştırmalarında müsteşriklerin metoduna karşı çıkanlar da bulunmaktadır. ${ }^{31}$

Kendinden önceki diğer oryantalistler gibi Jeffery de Kur'ân'ı Hz. Muhammed'in oluşturduğu bir kitap olarak telakki etmektedir. Ona göre Kur'ân, nihayetinde Hz. Muhammed'in kitabı olup ilk kelimesinden son

29. Jeffery, The Foreign Vocabulary of the Qur'an, s.38.

30. Jeffery, "Eclecticism in Islam", $M W, 12$ (1922) s. 246

31. Akdemir, "Müstç̧riklerin Kur'ân-ı Kerim ve Hz. Muhammed'e Yaklaşımları", $A \ddot{U} I F D$, Özel Sayı, c.XXXI, 1989, s.193. 
kelimesine kadar onun kişiliğini yansıtmaktadır. ${ }^{32}$ Jeffery, Kur'ân kelimelerinin kaynaklan konusunda yapmış olduğu çalışmanın sonuçlarını The Foreign Vocabulary of the Qur'an adlı eserinin giriş kısmında özetlemekte ve Kur'ân'ın orijinalitesini, İlâhî olma vasfını çürütmeye çalışmaktadır. Ona göre Kur'ân'ın yalnızca dinî kavramlarının büyük çoğunluğu değil, kültürel terminolojisi de Arap dışı kaynaklara dayanmaktadır. Yazar, Kur'ân'da Arapça olmayan üç farklı sözcük türünün bulunduğunu kabul etmektedir. 1- Arapça'da kökü bulunmayan ve tamamen yabancı olan kelimeler. 2- Üçlü kökü Arapça'da bulunabilen ancak Kur'ân'da bu kök anlamıyla değil diğer dillerde taşıdığı anlamıyla kullanılan Sami dillerden ödünç alınmış kelimeler. 3- Ash 1 Arapça olan ancak Kur'ân'daki kullanımı, akraba dillerdeki anlamıyla renklenmiş Arap̧̧a kelimeler. ${ }^{33}$ Kur'ân'daki bir çok yabancı kelimenin peygamberden önce de Arap Yarımadası'na girdiği ve kullanıldığını belirten Jeffery'ye göre Kur'ân'daki bazı kelimeler ise oraya bizzat peygamber tarafından eklenmiştir. Örneğin ona göre bazı Süryanice kelimeleri Peygamberin kendisi Kur'ân'a dahil etmiştir. Jeffery, bazı rivayetlere göre Peygamberin Süryanî Kilisesiyle kişisel temasının bulunduğunu iddia etmektedir. İleri sürdüğü tezleri desteklemek için de kullanabileceği hemen her türlü zayıf rivayeti zikretmeye çalışmaktadır. Örneğin $\mathrm{Hz}$. Peygamber'in küçüklüğünde Kureyş kervanlarıyla Suriye'ye seyahat yaptığını, Kuss ve Ukaz Panayırı'nda Necran piskoposunu dinlediğini; erken dönem Hristiyanlarının Sergius adlı bir rahibin onun akıl hocası olduğunu iddia ettiklerini; Nestur ve rahip Bahira hikayelerinin onun Hristiyanlarla ilişkilerini ispatladığını ileri sürmektedir. ${ }^{34}$

Arthur Jeffery, The Qur'an as Scripture' da ise İslâm dininde Kur'ân'ın merkezi konumundan ve hayatî öneminden hareketle biraz daha farklı bir tutum sergilemektedir. Bu eserinde İslâm dinindeki metin doktrinini ele almakta ve Kur'ân'ı bir fenomen olarak görerek diğer kutsal metinlerle karşılaştırmasını yapmaktadır. Kur'ân kavramlarını anlamaya ve çözümlemeye çalışan Jeffery'nin bu alandaki önemli bir vasfı da, Kitab-1 Mukaddes konusundaki bilgisi sebebiyle sık sık karşılaştırmalar yapmasıdır. Dilbilim alanında yetkin bir kişi olan Jeffery, bu eserinde kavramlan bizzat Kur'ân'dan hareketle anlamaya çalışmakta ve bunu gerçekleştirebilirse Peygamberin zihin dünyasının da çözülebileceğini ileri sürmektedir. ${ }^{35}$

32. Jeffery, Qur'an as Scripture, New York, Russel F. Moore Co, 1952. s.1.

33. Jeffery, The Foreign Vocabulary of the Qur'an, s.39-40.

34. Jeffery. The Foreign Vocabulary of the Qur'an, s.22.

35. Jeffery, Qur'an as Scripture, New York, 1952, s.69. Patrick O'Hair Cate, Each Other's Scripture, s. 240 
Jeffery'e göre Hz. Muhammed Kur'ân'ı oluştururken Yahudi ve Hristiyan çağdaşlarından öğrenmiş olduğu İlâhî kitaplarla ilgili Semavi Arketip düşüncesinden hareket ederek uzun bir yol kat etmiştir. Ona göre bu yolun gelişim süreci de gayet açıktır. Muhammed Ehl-i Kitab'tan öğrendiği bu vahiy kaynağını kullanarak, Hz. Musa'nın, Hz.Yusuf'un, Hz. Davud ve Hz. Süleyman'ın, Hz. İsa ve annesinin hikayelerini elde etmiştir. Çünkü bunlan kolaylıkla öğrenebilirdi. Aynı şekilde, Yahudi ve Hristiyanlardan geçmiş peygamberlerin özel ailevî meselelerini de elde etmiştir.

Hz.Yusuf'la Firavun'un vezirinin karısı, Hz. Musa'nın küçüklüğü ile Firavun'un kızı, Hz. Musa'nın Şuayb'ın kızları ile buluşması, Süleyman ve Saba Melikesi arasında cereyan eden olay, Zekeriyya'nın eşinin kısırlığı ve Yahya'nın vadedilmesi gibi geçmiş peygamberlerin özel ailevî meselelerinden bahseden hemen bütün kıssaları hep bu yolla elde etmiştir. ${ }^{36}$

$\mathrm{Hz}$. Peygamber'in Yahudi veya Hristiyanlardan sistematik bir eğitim almadığını, onlardan daha çok söylentiler yoluyla kulaktan dolma şifahî bilgiler edindiğini, bu açıdan da çok sayıda öğretmeninin bulunduğunu, peygamber kıssaları konusundaki Kitab-ı Mukaddes bilgisinin de Eski Ahid'den ziyade Rabbinic hikayelere dayandığını, bunun sonucu olarak da Kur'ân'daki bir çok kıssada çeşitli bilgi yanlışlıklarının bulunduğunu iddia etmektedir. ${ }^{37}$ Tabii bütün bu yaklaşımlarda Kitab-ı Mukaddes'in verileri temel alınmakta ve peygamber kıssaları konusunda asıl doğru bilgilerin orada bulunduğu inancından hareket edilmektedir. Oysa tarihî kaynak olma konusunda Kitab-ı Mukaddes'in güvenirliliği ve orada zikredilen kıssaların tarihsel gerçekliliği son derece tartışmalı olup Kitab-ı Mukaddes'e bu konuda çok ciddî eleştiriler yapılmaktadır. Dahası ileride de değinileceği gibi metin sıhhati açısından Kitab-ı Mukaddes'in, Kur'ân-ı Kerim ile kıyaslanması hiç de mümkün görünmemektedir. ${ }^{38}$

Jeffery; günümüzde Müslümanların elinde mevcut bulunan Kur’ân metninin Muhammed'in nübüvvet hayatı boyunca hâlâ varlığını sürdüren gerçek tebliğlerinin toplanması için yapılan dürüst bir çabayı temsil ettiğinde kuşku olmadığını belirtmektedir. Ancak Kur'ân'ın içine gerçek olmayan bir takım tebliğlerin de sızmasının pekala mümkün olduğunu, yine bir çok gerçek tebliğin de şimdiki metinde bulunmadığının kesin olduğunu ifade

36. Jeffery, Qur'an as Scripture, IV. makale, s. 268.

37. Jeffery, "Had Muhammad a Scripture Teacher?", MW, s.113-114; Foreign Vocabulary, s.29.

38. Bu konudaki değerlendirmeler için bkz. Gündüz, Şinasi, "Kur'ân Kıssalarının Kaynağı Eski Ahid mi? Yapı Muhteva ve Kaynak Açısından Torah Kıssaları", OMÜIFD, Samsun, 1998, sayı 10, s.49-88. 
etmektedir. ${ }^{39}$ Jeffery, Fatiha suresi ile Muavvizetân olarak da bilinen Felak ve Nas surelerinin çevirisini The Koran-Selected Surahs adlı eserine almış olmakla beraber bu surelerin Kur'ân'ın bir parçası olduğunu kabul etmemektedir. 'Sahip olduğumuz (Kur'ân) yüz on bir sure içermektedir' diyen Jeffery, Fatiha ile ilgili olarak onun Kur'ân'ın bir parçası olmadığını, tarz açısından diğer surelere benzemediğini, okumaya başlamadan önce dua etmek amacıyla kitabın başına sonradan yerleştirildiğini, bunun da Yakın Doğu'da kutsal kitaplar için uygulanan bir gelenek olduğunu belirtmektedir. ${ }^{40}$

Peygamberin hayatı konusunda yazılı en güvenilir kaynağın Kur'ân olduğunu, rivayetlerden ziyade ona dayanmak gerektiğini kabul eden Jeffery, bu noktada da 'Şayet bizim birincil dayanağımız Kur'ân olursa gelecek sorun, onun nasıl sağlam bir zemin sağlayacağını araştırmaktır. Genellikle en azından burada güvende olacağımız varsayılmaktadır, ancak Casanova ve Mingana'nın yaptıkları son çalışmalar, bu kaynağın bile güvenilirliği konusunda ciddi kuşkular uyandırmaktadır.' diyerek, Kur'ân'ın tarihî bakımdan sıhhatli bir metin olup olmadığı konusunda da kuşkularını dile getirmektedir ${ }^{4} 1 \mathrm{ki}$, bu noktadan sonra onun Kur'ân tarihine dair teorisine, bu konudaki görüşlerine ve Kur'ân metninin sıhhatini zayıflatmaya yönelik çabalarına geçebiliriz.

\section{3-Kur'ân Tarihi Teorisi}

Jeffery'nin Kur'ân tarihi teorisine geçmeden önce onun Müslümanların kabul ettikleri Kur'ân tarihi teorisine dair açıklamalanna değinmek gerekir. Ona göre İslâm'ın geleneksel olarak kabul gören metin tarihi teorisi, gayet iyi bilinmektedir. Bu teoriye göre peygamber, Cebrail aracılığı ile yirmi küsur yılda parçalar halinde kendisine gelen vahiyleri bir yandan ezberleyip diğer yandan da vahiy katiplerine yazdırmışır. Yine her yıl ramazan ayında o tarihe kadar inen vahiylerin doğru kaydedilip edilmediğini kontrol etmek için Cebrail'le peygamber arasında karşılıklı olarak eda ve arz gerçekleşmiştir. İlahî vahiyler bu şekilde hem ezberlenerek hem de yazıya geçirilerek koruma altına alınmıştır. Ancak bu vahiyler peygamber hayattayken iki kapak arasına alınarak bir kitap haline getirilememiştir. Hz. Peygamber'in vefatından sonra Yemame Savaşı'nda yetmiş kadar Kurra'nın şehid olması üzerine endişeye kapılan $\mathrm{Hz}$. Ömer'in teklifi ve ilk halife Hz. Ebu Bekir'in

39. Jeffery, "Abu Ubaid on The Verses Missing From Qur'an", $M W, 28(1938)$ s.61

40. Jeffery, "A Variant Text of the Fatiha", MW, 29 (1939) s.158; The Koran-Selected Surahs, New York, Heritage Press,1958, s.15-23.

41. Jeffery. "The Quest of Historical Muhammad", $M W$, s.342. 
de kabulü üzerine, Zeyd b. Sabit'in çabalanyla ilk resmî cem hadisesi gerçekleşmiş ve Kur'ân mushaf haline getirilmiştir. Hz. Ebu Bekir'den sonra bu mushaf $\mathrm{Hz}$. Ömer'e, onun vefatından sonra da kızı Hz. Hafsa'ya geçmiştir. Üçüncü halife Hz. Osman döneminde de lehçe ve kıraât farklılıklan ortaya çıkınca Hz. Hafsa'dan istenen bu mushaf yine Zeyd b. Sabit başkanlığındaki bir heyet tarafından çoğaltılarak büyük şehirlere gönderilmiştir. Halen Müslümanlar arasında kullanılmakta olan Kur'ân metni, bu İmam mushafa ve ondan istinsah edilerek çoğaltılan mushaflara dayanmaktadır. ${ }^{42}$

Jeffery'ye göre Müslümanların geçerli olarak kabul ettiği bu hikaye büyük oranda hayalîdir. Ona göre hiç bir şey Peygamber öldüğünde toplanmış, düzenlenmiş, karşılaştırılmış bir vahiyler bütünü bulunmadığından daha kesin değildir. Ona göre Muhammed ashabına tıpkı Ehl-i Kitab'ın sahip olduğu gibi bir kutsal kitap bırakmayı düşünmüş ancak bunu gerçekleştiremeden vefat etmiştir. Onun bu tasarısı sonradan hayata geçirilmiştir. Müsteşriğimiz, vahiy malzemesini toplatanlardan birinin Ebu Bekir olduğunu, onun muhtemelen Peygamberin bir Kitap için biriktirdiği malzemeyi de tevarüs ettiğini kabul etmektedir. Ancak Müslümanlar tarafından ileri sürüldüğü şekilde bunun resmî bir cem değil, aksine çok sayıdaki diğer sahabenin kişisel olarak yaptıkları koleksiyonları gibi tamamen özel bir iş ve ilk metin tespiti olduğu tezini savunmaktadır. ${ }^{43}$

Jeffery, Müslümanlar tarafından Hz. Ebu Bekir'in cemettiği resmî mushafı çoğaltma ve insanlanı tek lehçe/kıraât etrafında toplama girişimi olarak değerlendirilen $\mathrm{Hz}$. Osman'ın çabasını ${ }^{44}$ da yeni bir metin tespiti olarak değerlendirerek, Hz. Osman'ın amacının yalnızca okumadaki lehçe farklılıklarını kaldırmak değil, tüm imparatorluk için standart bir metin tayinine yönelik zorunlu bir siyasî çaba olduğu görüşündedir. Bu dönemde

42. Jeffery, Materials for the History of the Text of the Qur'an, s.4-5; "The Textual History of the Qur'an", The Journal of Middle East Society, I (1947), Part II, s.40.

43. Jeffery, Materials for the History of the Text of the Qur'an, s.4-5.

44. "Hz. Osman, Camiu'l-Kur'ân olarak tanınmaktadır. Bu, Kur'ân'ı onun bir araya getirdiği anlamına gelmemektedir. Müslüman tarihçiler bu ünvanı, Hz. Osman'ın Mứslümanları tek tip bir okuma etrafında birleştirmiş olması anlamında yorumlamaktadır. O Müslümanlanı telaffuz farklılıklarından kurtarmak için Mekke telaffuzunu seçmiştir." Hamidullah Muhammed, Islam'ın Doğuşu, ç. Murat Çiftkaya, Beyan Yay. İst, 1997, s.30; Hamidullah hocanın burada Hz. Osman'ın girişimi ile ilgili olarak dile getirdiği 'tek tip bir okuma etrafında birleştirme' ifadesini -şayet çeviri hatası yoksa- Kıraâtten ziyade Müslümanları tek bir lchçe olan Kureyş lehçesinde toplama olarak anlamanın daha doğru olacağı kanaatindeyiz. Zira Kıraât farklılıklan daha sonra da devam etmiş ancak $\mathrm{Hz}$. Osman'dan sonra lehçe olarak yalnızca Kureyş lehçesi kabul görmüştür. Bu konuda daha ayrıntılı bir değerlendirme için bkz. et-Tabeñ, Câmiu'l Beyan, Daru'l Fikr, Beyrut, 1988, I, 18-21. 
farklı bir çok büyük şehirde sahabe tarafından bir takım özel koleksiyonlar yapıldığını ve bunlar arasındaki geniş farklılıklann Medine, Mekke, Basra, Kufe ve Şam gibi büyük şehir merkezlerindeki Mushaflara da sinmiş olduğunu ileri sürmektedir. Bunun sonucu olarak standart bir metne sahip olmanın siyasî zorunluluk haline geldiğini ve Hz. Osman'ın çözümünün de Medine Mushaf'ını resmîleştirmek ve diğerlerinin tamamının imhasını emretmek olduğunu, ancak ileri gelen Kurra'nın, Hz. Osman'ın bu eylemine şiddetle muhalefet ettiğini ve Kufe Müslümanlarının, İbn Mesud Mushafi'nın yakılmasını reddederek onda direnenlerle Hz. Osman'ın metnini kabul edenler şeklinde iki gruba bölündüğünü gösteren kanıtlar bulunduğunu iddia etmektedir. ${ }^{45}$ Ona göre Hz. Osman'a kadar bir çok mushafın varlığından ve tarihinden bahsedilmesi mümkün iken Osman Mushafı'ndan sonra artık bir tek musafhın tarihini izlemekteyiz.

Hz. Osman'nın resmîleştirdiği metnin sessiz harfli bir metin olduğunu, standart hale getirilen metnin bu haliyle bile çok değişik şekillerde okunmaya müsait bulunduğunu, noktalama ve harekelemenin sonradan ortaya çıktığını ileri süren Jeffery, bundan sonrası için çok ilginç iddialarda da bulunmaktadır. Örneğin ona göre Kur'ân'ın metinleşmesi tarihinde Haccac b. Yusuf yalnızca Kur'ân'ın hareke ve noktalanmasını sağlamakla yetinmeyip yeni bir metin tespiti yaptırmıştır. Böylece Kur'ân tarihinde metnin bir kaç kez yeniden oluşturulduğu şeklinde kendine özgü bir tezi savunan Jeffery, bu yolla Kur'ân'ın metinleşmesi tarihinde bir takım kuşkulara yol açmaya, Kur'ân metninin sıhhatini ve güvenirliliğini sarsmaya çalışmaktadır.

"Osman tarafından geçerli sayılan metnin, o dönmede var olan bir çok metin türünden yalnızca biri olduğunda kuşku yoktur. ${ }^{46 "}$ diyen Jeffery, başka bir yerde de "Osman tarafından resmîleştirilen metin bir çok rakip metin'den yalnızca biridir, ve bizim araştırmak için bu resmî metnin öncesine gitmemiz gerekir"47 demekte ve Hz. Osman'ın Kur'ân'ı çoğaltarak büyük şehir merkezlerine gönderdiği tarihten önce çok sayıda sahabe mushafının bulunduğunu ve bunlann merkezî konumu elde etmek için birbirleriyle rekabet ettiklerini iddia etmektedir. Bu şekilde varlığını iddia ettiği çok sayıdaki sahabe mushaflarını da birbiriyle yarışan 'rakip mushaflar' (rival codices) olarak görmektedir. Birbiriyle rakip olan bu çok sayıdaki kişisel mushaflar tezinden hareketle de, Kitab-1 Mukaddes geleneğinde olduğu gibi

45. Jeffery, "Progress in the Study of the Qur'an Text", MW, 25(1935), s.7-8; Materials for the History of the Text of the Qur'an, s.8.

46. Jeffery, Materials for the History of the Text of the Qur'an, s.8.

47. Jeffery, Materials for the History of the Text of the Qur'an, s. 8. 
Kur'ân tarihinde de içerikleri değişiklikler gösteren bir çok farklı Kur'ân nüshalarının bulunduğunu dolayısıyla onun da metin tenkidinin yapılmasının zorunlu olduğunu vurgulamaktadır.

\section{4- Kıraât Farklılıklanna Yaklaşımı ve Kur'ân'ın Metin Tenkidi Projesi}

Jeffery'nin kıraât farklılıkları ve Kur'ân'ın metin tenkidine yönelik çabalarına geçmeden önce kısaca metin tenkidinin mahiyetine değinmekte yarar görüyoruz.

Hakiki olanı sahte olandan ayırma sanatı olarak tarif edilen tenkit ilminin batı dünyasında XVI. yüzyılda doğduğu iddia edilmektedir. Başlangıçta daha çok tarihe ve tarihî belgelere uygulanan tenkit ilmi, "tarihî tenkit" deyiminin ortaya çıkmasına neden olmuştur. 1- Dış tenkit ve 2- İç tenkit olarak ikiye ayrılan tarihî tenkit ilminde, dış tenkitte kaynakların kritiği yapılırken; iç tenkitte metnin muhtevasının kritiği yapılmaktadır. Bu da kendi içinde olumlu ve olumsuz tenkit olmak üzere ikiye ayrılmaktadır.

Tarihî tenkidin yanı sıra başka türleri de bulunan ve batı dünyasında büyük bir gelişme gösteren tenkid ilminin bir diğer tasnifi de 1- Basit tenkit ve 2- Derin tenkit şeklinde yapılmaktadır. Basit tenkitte (lower criticism) metin, belge ve kitaplarla meşgul olunarak imkan ölçüsünde yazma nüshalardan faydalanılmaktadır. Tercümeler ve atıflar bir araya toplanarak tenkidi yapılan metnin, ilk hali ile düzenlenmesine çalışılmaktadır. Bu yönü ile basit tenkide "metin tenkidi" adı da verilmektedir. Derin tenkitte (higher criticism) ise araştırmalar eserlerin veya belgelerin kaynağına, yazarlarına, tarihlerine, kaynaklarına, yazılı̧ tarzlarına ve edebî türlerine yöneltilir. Bu yönü ile bu tenkide "edebî tenkit"de denilmektedir. ${ }^{48}$

Bilindiği gibi Tevrat ve Incil'in metinleşme süreci uzun bir tarih dilimine yayılarak gerçekleşmiştir. Tarihî tecrübe Kitab-l Mukaddes'in birbirinden farklı olan yazmalarının bulunması ve bunların doğruluklarının ilmî yöntemlerle tespitini zorunlu kılmıştır. Yapılan yazma mukayeseleri sonucunda metinlerde yüz binlere varan farklılıkların bulunması batı aleminde yukarıda değindiğimiz 'metin tenkidi' denen usulü doğurmuştur. Yapılan yoğun çalışmalar sonucunda metin tenkidi batı dünyasında çok büyük bir gelişme göstererek önemli bir literatürün doğmasını sağlamıştır. ${ }^{49}$

Batı dünyasındaki bu yöntem oryantalistler tarafından Kur'ân'a da uygulanmak istenmiş ve Derenbourg, R. Geyer ve Ignaz Goldziher gibi oryantalistler uzun yıllar Batılıların ihtiyaçlarına cevap verecek tenkitli bir

48. Kuzgun, Şaban, Dört Incil Farklllıklart ve Celişkileri l, Ist.1991, s.61-62.

49. Kavakçı, Y. Ziya, Islam Araşırmalarında Usul, Ank, 1982, s.82. 
Kur'ân neşrini düşünmüşlerdir. ${ }^{50}$ İslâm dininde Kur'ân'ın önemini ve merkezî durumunu farkeden müsteşrikler bu dinin kutsal kitabının mevsukiyeti konusunda kuşkulara yol açmak veya en azından kendi kutsal kitaplarının seviyesine indirmek için çaba ve gayret göstermekten geri durmamışlardır. ${ }^{51}$ Nitekim Jeffery, Kur'ân'ın Müslümanlar için ne anlama geldiğini ortaya koyma bağlamında bir yerde zaman zaman insanlar arasında "İncil'siz bir Hristiyanlık mümkün olabilirdi, ancak Kur'ân'sız bir İslâm asla!" şeklinde bir deyişin var olduğunu naklederek bu gerçeğe işaret etmekte ve Kur'ân'ın merkezî otoritesini kabul ederek hedef noktasına onu almaktadır. ${ }^{52}$

Tevrat ve İncil'in metin olarak çok farkh nüshalarının bulunduğu gerçeğini kabul ve itiraf eden ${ }^{53}$ Jeffery, Eski ve Yeni Ahid'in metinleşme sürecindeki evrimleşmeyi, aynen Kur'ân'ın metinleşmesine de uygulamak istediğinden, daha önce de değindiğimiz gibi Hz. Osman Mushafı öncesinde mevcut olan Mushaflardaki kıraât ve lehçe farklılıklarının tamamını derleme ve yayımlama projesine girişmiştir. Kur'ân kıraâtlerine dair mütevatir ve şazz bütün farklılıklan bulabildiği tüm tefsir, hadis, lugat, edebiyat ve dinî literatürden derlemek suretiyle, Kur'ân'ın metin tenkidini yapmaya çalışmıştır. ${ }^{54}$ Onun bu amaçla derlemiş olduğu farklılıklar Materials for the History of the Text of the Qur'an (Old Codices) adlı eserinde ve çeşitli dergilerde yayımlanan makalelerinde yer almaktadır. Materials'daki kıraât farklılıklarının çoğu İbn Ebi Davud'un eserinden alınmı̧ olup bir çoğu da Materials'ın giriş kısmında zikredilen kaynaklardan toplanmıştır. ${ }^{55} \mathrm{~Hz}$. Osman mushafı öncesine ait on beş adet 'birincil' mushaf, on üç adet de 'ikincil' mushaf adı zikrederek bunlara ait farklı varyantlanı toplamaya çalışan Jeffery, bulabildiği bütün lugat, tefsir, kıraât ve edebî eserlerden yararlanarak yaklaşık olarak altı bin civarında farklı kıraâtin derlemesini yapmışır. ${ }^{56}$

İbn Ebi Davud, Kitabu'l Mesahif'inde Jeffery'den daha açık ve net olarak mushaf sözcüğünü harf veya kıraât anlamında kullandığını, naklettiği

50. Ccrrahoğlu, "Oryantalizm ve Batıda Kur'ân ve Kur'ân flimleri Uzerine Araştırmalar", s.110.

51. Cerrahoglu, a.g.m. s.129.

52. Jeffery, Qur'an as Scripture, s.1.

53. Jeffery, "Mukaddime" (Kitabu'l Mesahif içinde), s.3-4; "The Textual History of the Qur'an", s.41; Nakra Tihamî, "el-Kur'ân ve'l Müsteşrikun", (Menahicu'l Müsteşrikin içinde) I, 40.

54. Badeu, "A.Jeffery- A Tribute", s. 50.

55. Jeffery, Materials, s.17-18.

56. Chaudhary, "Orientalism on Variant Readings of the Qur'an: The Case of Arthur Jeffery", AJISS, c.XIl, 2 (1995), s. 171,172. 
kıraât farklılıklarının gerçekte şahıslara ait yazılı mushaflardan nakledildiği şeklinde kabul edilmemesi gerektiğini aktarmaktadır.57 Ancak Jeffery, Kitabu'l Mesahif'deki bu ifadelerin metne sonradan dahil edildiği ve dolayısıyla söz konusu eserde 'mushaf' denince Hz. Osman Mushafı dışında diğer sahabenin sahip olduklan kişisel derlemelerinden oluşan bir Mushaf'ın (Codex) kasdedildiği kanaatini taşımaktadır. ${ }^{58}$ Bu kanaatın bir sonucu olarak da söz konusu mushafların farklı varyantlarının yalnızca kıraât farklılıklarından ibaret olmadığını metin olarak da birbirlerinden farklı oldukları tezini ortaya atarak yapacağı çalışmanın $\mathrm{Hz}$. Osman öncesine ait daha eski bir Kur'ân metninin ortaya çıkarılmasına imkan vereceğini ümit etmiştir.

Kur'ân'ın metinleşme tarihi ile ilgilenen ve farklı mushaflardaki muhtelif okumaları derlemeye çalışan Jeffery, bu alanda Alman müsteşrik Gotthelf Bergsträsser ile işbirliği yapmak suretiyle ortak bir proje etrafında çalışmalar yürüterek tenkitli bir Kur'ân neşrini gerçekleştirmeyi düşünmüştür. Bu proje çerçevesinde bir yandan farklı kıraâtlerin derlemesi yapılırken diğer yandan da Münih'te bir Kur'ân Arşivi kurulmuş ve dünyanın muhtelif yerlerindeki eski mushaflar fotoğraflanarak aralarında metinsel farklılıkların bulunup bulunmadığının tespitine başlanmıştır. Projenin yürütülmesini uhdesine alan Bergsträsser'in 1933 yllında çalışmayı tamamlayamadan vefat etmesi üzerine, bu görevi öğrencisi olan Otto Pretzl devralmıştır. Jeffery aynı kişiyle de görüşerek projenin sürdürülmesine çalışmışır. Projeyi uzun süre devam ettiren Otto Pretzl, İkinci Dünya Savaşı'nda Sivastopol yakınlarında öldürülmüş ve kurulan Kur'ân Arşivi de müttefik bombardımanları sonucu yanarak tamamen yok olmuştur. Çalışmalarına ara vermeyen Jeffery, 1959 yılına. yani vefatına kadar Kur'ân ilimleri alanındaki çabalarını sürdürmüşse de söz konusu proje bir türlü hayata geçirilememiştir. İkinci Dünya Savaşı sonrasında yazmış olduğu bir makalesinde Jeffery, proje ile igili yapılan çalışmalara değinmekte ve bu çalışmada Arşiv'in yıkılmasına yönelik bilgilere yer vermektedir. Savaş dönemine kadar yapılmış olan bütün çalışmaların bu bombardıman sonucu yeniden baştan başlamayı gerektirecek şekilde tamamen heba olduğunu belirten Jeffery, projenin sonuçsuz kalmasından duyduğu üzüntülerini dile getirmekte ve nihâ̂ kanaatini, kendi kuşağının tenkitli bir Kur'ân metninin

57. Ibn Ebi Davud, Kitabu'l-Mesahif, s.50; Jeffery, Materials for the History of the Text of the Qur'an, s.13; Chaudhary, "Orientalism on Variant Readings of the Qur'an", s.182.

58. Jeffery, Materials for the History of the Text of the Qur'an, s. 13; Watt, Montgomery, Kur'ân'a Giriş, ç. S. Kalkan, Ankara, 2000, s.59. 
neşredildiğini görmelerinden artık son derece kuşku duyduğunu vurgulayarak tamamlamaktadır. ${ }^{59}$

Kur'ân'ın metin tenkidi projesinin yürütüldüğü tarihlerde kıraâtler konusuna duyulan batı dünyasındaki yoğun ilgi sayesinde, çok sayıda İslâmî eserin müsteşrikler tarafından tahkikli ve tenkitli neşrinin yapılarak ilim âlemine kazandırıldığını belirtmemiz gerekir. Niyet, amaç ve beklentileri değişik olsa da, yaptıkları çabalar bekledikleri sonucu vermese de, Kur'ân tarihi ve kıraâtleri konusuna gösterilen batı dünyasındaki bu yoğun ilginin, İslâm dünyasında da benzer çalışmaların tespiti ve neşri konusundaki çabalara ivme kazandırdığını vurgulamalıyız. Jeffery ve arkadaşlarının yaptıkları çalışmalar çerçevesinde değerlendirmek üzere ulaşmayı ve yayımlamayı arzu edip de başaramadıkları Kur'ân tarihi ve kıraâtleri ile ilgili bir çok çalışmanın, daha sonraki tarihlerde neşredilerek ilim dünyasına kazandırıldığını ve bu sürecin hâlâ devam ettiğini de memnuniyetle belirtmek gerekir.

\section{5- Jeffery'nin Çabalarına Yönelik Değerlendirme ve Eleştiriler}

Arthur Jeffery'nin, Kur'ân ilimleri alanındaki çalışmaları, Kur'ân tarihi teorisi, yapmıs olduğu kıraât derlemeleri, kullandığı bazı kaynakların geçerliliği, bunlan değerlendirme biçimi, yer yer düştüğu çelişkiler ve son olarak Kur'ân'ın metin tenkidi projesine yönelik çabaları konusunda, hem Müslüman araştırmacılar hem de batı dünyasındaki oryantalistler tarafından yapılmış olan olumlu veya olumsuz görüş ve değerlendirmeler, ortaya atmış olduğu tezlere yönelik ciddî eleştiriler de bulunmaktadır.

Jeffery ve meslektaşlarının yaptıkları çalışmalar ve Kur'ân'ın metin tenkidine yönelik çabaları konusunda Alman müsteşrik Rudi Paret'ten aktardığımız aşağıdaki açıklamalar konuyla ilgili çabaların sonuçlanna dair oldukça çarpıcı değerlendirmeler içermektedir:

"Uzun bir süre, tefsirlerde nakledilen ve hususî eserlerde biraraya getirilmiş olan bu farklı kuraât tarzlarının. Osman öncesine ait daha eski bir Kur'ân metninin ortaya çıkarılmasına imkan vereceği ümit edildi. Münih'li şarkiyaţ̧ı Gotthelf Bergstrasser ve onun halefi Otto Pretzl, Bayern Bilimler Akademisi'nin talebi üzerine el yazması olarak bugüne ulaşmıs bulunan varyantları toplayarak, yazma eserlere dayalı tenkitli bir kiraât varyantları mecmuası (Apparat) hazırlamak üzere çalışmaya başlamışlardı. Aymı zamanda Amerikalı şarkiyatçı Arthur Jeffery de edebî kaynaklardan çıkabilecek malzemeyi tenkitli bir mecmua halinde derlemeyi düşünüyordu. Her ü̧ bilim adam da projelerini gerçekleştiremeden vefat ettiler; en son, bir yll kadar önce Arthur Jeffery öldü. Bu projeyi yeniden ele alıp sonuca ulaşırmaya kendisini hazır hissedecek birisi çıar mı, bilmem. Çünkü bu süre zarfında Kur'ân varyantlarının değeri ile ilgili oldukça olumsuz bir kanaat

59. Jeffery, "The Textual History of the Qur'an", JMES I (1947), Part II, s.49. 
hasıl oldu. Leipzigli şarkiyaţ̧ı August Fischer ölününden sonra 1948'de Der Islam'da neşredilen yazısında bu konudaki fikrini şöyle dile getiriyor. "Kanimca büyük ölçüde filoloji eğitimi almuş Kur'ân araştırıcılarının. Osman mushafının müskilatlı pasajları üzerinde yapıklart tahkik girişiminden başka bir şey olmayan bu 'kıraâtler' konusu, son yirmi yılda Bergstrasser ile onun hem talebesi hem de bu çalışmada yardımcısı olan Pretzl ve Jeffery'nin etkisiyle gereğinden fazla abartıldı." Taberî Tefsiri'ndeki yüzlerce varyanttan fikan sonuç, Fischer'in bu olumsuz kanaatini teyid etmektedir. Ama yine de ilgili malzemenin daha ayrinthl bir biçimde tasnif edilmesi gerekebilir. Bize ulaşan ktraât şekillerinin büyük bir bölümü gerçekten "filoloji uzmam Kur'ân araştırıcılarının tahkik denemesi" ólarak nitelenmeye elverişlidir. Bazı durumlarda deyim yerindeyse filolojik oyunlardan bile sözedilebilir. "60

Rudi Paret, başka bir yerde de aralarına Arthur Jeffery'yi de katarak Avrupa ve Amerika Oryantalizmi'nin temsilcilerinin Kur'ân'ın metin tenkidine yönelik uzun süren çabalarını ve bu işle yoğun bir şekilde uğraşanların vardıkları son noktaya dair şunlanı söylemektedir:

"Avrupa ve (Amerika) Oryantalizmi'nin temsilcileri, Kur'ân varyantlarınt biraraya toplamak ve bunları tarihsel eleştiri yönteniyle yorumlamak için çok çaba sarfetmişlerdi. (Nöldeke'den sonra) konuyu yeniden tartışmaya açan Goldziher'i; Arthur Jeffery, Gotthelf Bergstrasser, Otto Pretzl ve Edmund Beck izlemiştir. Gerçi August Fischer, ölümünden sonra yayımlanan bir makalesinde Bergsrasser ve Pretzl'in çalısmalariyla ilgili olarak, Pretz'lin, ömrünün son yıllarında Kur'ân yazmalarına ve Kur'ân kıraâtlarına arık fazla dĕ̆er verınediğine dikkat çekmektedir. Fischer kendi payına bu kırâat tarzları meselesinin "büyük ölçüde, filoloji eğitimi almıs Kur'ân araştırıcılarının, Osman nüshası'nın müşkilatl pasajları üzerinde yaptıkları bir tahkik denemesinden başka bir şey olmadı̆̆ı" kanaatini taşımaktadır. Ama 'büyük ölçüde' ifadesini basımda espase dizdirmiştir. Her şeye rağmen -az sayıda da olsa-bir grup varyant vardır ki, asıl metni tespit etmeye çalışırken bunlara da başvurulması gerekir."61

Burada dikkati çeken nokta Otto Pretzl'in ömrünün son yıllarında Kur'ân yazmalarına ve Kur'ân kıraâtlerine artık eskisi kadar fazla değer vermediğine dair tespittir. Bu tespiti destekleyen bir diğer canlı tanık da Muhammed Hamidullah'tır ki onun açıklamasına birazdan değineceğiz.

Jeffery ve arkadaşlanıı çabalarını destekleyenler arasında Andrew Rippin'i sayabiliriz. Rippin, Jeffery'nin The Present Status of Quranic Studies (1957) adlı makalesini yayımlamasının üzerinden yirmi beş yıl

60. Paret Rudi, Kur'ân Üzerine Makaleler, \&. Ömer Özsoy, Ank, 1995, s.121. Paret, Kur'ân'ın mevsukiyeti konusunda Jeffery ve benzeri müsteşriklere göre çok daha insaflı görünmektedir. "Hiç bir din kurucusunun mesajı Muhammed'in tebliği kadar güvenli bir şekilde bugüne intikal etmemiştir. Bu son kitabî dinin kurucusu tarafından 610-632 yılları arasında teblił̧ edilip, onun vefatından yirmi yıl sonra Osman mushafı aracılığı ile tespit edilen bu metinler, haklılıkla mevsuk olarak nitelenebilirler." Paret, Kur'ân Üzerine Makaleler, s.169.

61. Paret, Kur'ân Üzerine Makaleler, s.169-170. 
geçtikten sonra The Present Status of Tafsir Studies başlıklı bir makale yayımlayarak aradan geçen süre zarfındaki gelişmelerle ilgili bazı değerlendirmeler yapmaktadır. ${ }^{62}$

Rippin, Jeffery'nin döneminde bir çok insanın temel ilgisinin tenkitli bir Kur'ân metni oluşturmak olduğunu, böyle bir çalışmaya duyulan ihtiyacın hâlâ devam ettiğini, ancak onların bu projesinin gerçekleşmediğini, ne yazık ki gerçekleşecek gibi de görünmediğini belirtmektedir. Rippin, Jeffery'nin bütün dikkatini bu proje için hammadde olacak mahiyyetteki temel Arapça kaynaklanın toplanması üzerine yoğunlaşıırdığını belirterek, bugün $\mathrm{o}$ kaynaklardan bir çoğunun basılıp yayımlandığına, bu kaynak toplama ve yayımlama sürecinin halen devam etmekte olduğuna dikkat çekmektedir. ${ }^{63}$ Ancak, bunca kaynağın toplanıp yayımlanmış olmasına rağmen tenkitli metin konusunun artık eski cazibesini yitirdiğinden yakınmakta; kendisinin bu malzeme etrafında yeni ve farklı bir ilgi inşa etmeye çalıştığını belirtmektedir. Rippin, Kur'ân kıraâtlerine ilişkin halihazırda toplanmış olan bu devasa malzemenin Jeffery ve arkadaşlarının başlangıçtaki hedefleri doğrultusunda kullanılmasalar da önemli bir birikim olduğunu düşünmekte ve bu birikimin daha farklı amaçlarla kullanılıp kullanılamayacağını sorgulamaktadır. Bu bağlamda, toplanmı̧ olan malzemenin en azından uygun bir tarihî perspektife yerleştirilerek, ilk kez gün ışı̆̆ına çıktıkları çağların tefsir eğilim ve anlayışlarının çözümlenmesinde yardımcı olabileceğine işaret etmektedir ${ }^{64}$

Jeffery ve seleflerinin çabalarına yönelik İslâm dünyasında yapılan değerlendirme ve eleştirilere ise Muhammed Hamidullah'la başlayabiliriz. Hamidullah, batılıların İncillerin metin tenkidinde kullandıklan yöntemin, aralarındaki mahiyet farkından dolayı Kur'ân'a uygulanamayacağını belirterek şunları söylemektedir:

"Incillerin metin tenkidini Kur'ân'a uygulama arzusu kabili kıyas değildir. Zira bazı Islâm âlimleri Incilleri hadislere benzetirlerken bazıları Incillerin ne Kur'ân'a ne de hadislere benzemediğini zira Incillerin $\mathrm{Hz}$. İsa'nın biyografisi olduklarını, dolayısıly onların olsa olsa bir kısmı sahabe dönemine bir kısmı ise

62. Rippin, Andrew, "The Present Status of Tafsir Studies", Hamdard Islamicus, Kış, 1983, s.17-18.

63. Bunlar arasında ömek olarak İbn Mücahid'in Kitâbu's Seb'a fil-kıraât't (Kahire, 1980) Mekki el-Kaysî'nin el-Keşf an vucûhi'l-kıraâti's-seb'a'st (Dımeşk, 1974) İbnu'l Enban̂'nin, Kitâbu Mersûmi'l-hatt't (Yeni Delhi, 1977) ve Kitâbu'l Maktu ve'lmevsûl"unu (Rampur. 1980) saymakta, bu son ikisinin tartışmaların sınırlarını edDani'den bir asır öncesine göturrecek kadar eski temel kaynaklar olduğunu vurgulamaktadir. Rippin, "The Present Status of Tafsir Studies", s.17.

64. Rippin, The Present Status of Tafsir Studies, s.18. 
daha sonraki dönemlere ait siyer kitaplarına ve Hz. Muhammed'in biyografisine benzetilebileceklerini vurgulamaktadırlar. "65

Hamidullah, konunun daha net anlaşılabilmesi ve Kur'ân'la karşılaştırılması açısından batı dünyasında Kitab-ı Mukaddes'in metin tenkidine yönelik yıllarca süren çalışmalarla ilgili bilgiler de vermekte ve bu çalışmaların sonucunda yayımlanan raporun çarpıcı sonuçlar içerdiğine değinmektedir. Söz konusu raporda şu ifadeye yer verilmiştir: "Birbiriyle çelişen yaklaşık ikiyüz bin nakil bulunmuştur."66

Hamidullah, Arthur Jeffery'nin ortak proje yürüttügüü Otto Pretzl'in Kur'ân konusundaki çabaları ile ilgili olarak da şu bilgiyi vermektedir:

"Münih Üniversitesi'ndeki bazı kimseler Kur'ân'ı kıskanmış olsa gerek ki bir Kur'âni Araştırmalar Enstitüsü kuruldu. Hedef orjinali ya da fotokopisi mevcut olan en eski Kur'ân-ı Kerim nüshalarımn hepsini toplamaktı. Toplama süreci ü̧ kuşak boyunca sürdü. Ben 1933 yllinda Paris Üniversitesi'nde iken, enstitünün ü̧̧üncü müdürü, Mr. Otto Pretzl, Paris Devlet Kütüphanesi'nde bulunan bütün eski Kur'ân-t Kerim yazmalarının fotokopilerini almak için Paris'e gelmişti. Bu profesör o zaman bana, Enstitü'de Kur'ân-ı Kerim'in 43000 fotokopisinin bulunduğunu ve karşılaştırma işinin hızla sürdüğünü anlattı. Ikinci Dünya Savaşı sırasında Enstitü binasina bir bomba düşï ve hem kocaman binayı ve kütüphaneyi hem de çalışanlart imha etti. İkinci Dünya Savaşı başlamadan kısa bir süre önce yayımlanan geçici bir raporda, başka hususların yamsıra, Kur'ân yazmalarını toplama işinin henüz tamamlanmadiğı da belirtiliyordu. Fakat o zamana kadar yürütülen incelemelerin sonucunda, yazmalarda bazı hat yanlışları bulunmuşsa da, metinde tek bir çelişkinin bile bulunmadığı ortaya çıkı. Bir yazmada bulunan bir hat ya da matbaa hatast başka bir metinde yinelenmemektedir. Mesela, diyelim ki bir Kur'ân el yazmasında bir kelime metinde eksik olsun. Bu eksiklik, yanlışlıkla o kelimeyi atlayan katibin ihmalinden kaynaklanmaktadir. Nakilde böyle bir farkllik olsaydı, bir çok yazmada bulunurdu. Kur'ân için böyle bir şey söz konusu değildir." 67

İslam dünyasında Arthur Jeffery'nin kıraâtler konusundaki yaklaşımına ve metin tenkidi konusundaki girişimlerine karşı büyük tepki gösteren ve ağır eleştiriler yöneltenlerden biri de hiç kuşkusuz M. Abdullah Draz'dır. Draz, Kuran'a Giriş adlı eserinde Jeffery'nin, gerek Kur'ân Tarihi teorisine gerekse kıraâtler konusuna İlâm dünyasının ilgi göstermediği ve bu tür çabaların yeni olduğu şeklindeki değerlendirmelerine son derece ağır tenkitler yöneltmektedir:

"Ne var ki namaz. ve Mushaf dışında, bu resınî olmayan kırâatlerden herhangi bir sekilde istifade etmek tamamen serbesttir. Zaten İslâm ulemast da bu kuraâtlere daima ilgi duymuştur. Ancak Kitabu'l-Mesahif'in naşiri Dr. Arthur Jeffery bu konuda doğruyu görememiştir. Önce onun iddia ettĭğ gibi "böyle bir araşırma

65. Hamidullah, Kur'ân-t Kerim Tarihi, ç. A. Hatip. M. Kanık, Beyan Yay. Ist, 2000, s.19

66. Hamidullah, Islam'in Doğuşu. ç. Murat Çiftkaya, İst. 1997, s.31.

67. Hamidullah, İslam' 'n Doğuşu, s.31-32. 
Islâm âleminde yeni" değildir. Nitekim bu konuyla ilgili olarak, bizzat kendisinin kullanmıई olduğu Arap̧̧a kaynaklar, onun yanıldı̆̆ını açıkça ortaya koymaktadır. Bu ferdi kıraûtlere; otograf (ortograf), fonetik ve kıraâtle ilgili hususî eserlerin yantnda, tefsir, nahiv, hadis ve fikı kitapları da ̧̧ok geniş bir yer vermektedir. Sonra "Ehl-i Sünnet' in baskısına maruz. kalmak şöyle dursun, bu ferdi kıraâtler hâlâ mukaddes bir özellik taşımakıa ve Sünnî mezhepler tarafından, şüphesiz. Kur'ân metni olarak değil, fakat âhâd haberler olarak kullantlmaktadır. Bütün bu delillere rağmen, adı geçen Ingiliz misyonerinin içine, yakından tanıdı ̆̆ Hristiyan Kilisesi'nin tarih imajt o derece işlenmiştir ki, Islâmî sahadaki yazılarında bile onun tesirinden kendisini kurtaramadığı görülmektedir. O, Kur'ân-ı Kerim'in metninde, Incil'dekine benzeyen bir tekamülün varlığını ortaya koymağa çalışıyor; bunun için de işe, önce, muhtemelen vahyedildiği zaman yazılmıs olan, ibadetle ilgili bazı ayetlerle, yazılmamıs olan diğer ayetleri aytnnakla başlıyor. Neticede felişkiye düşerek, Hz. Peygamber'in vefatmda bile vahiylerin henüz tedvin edilmediğini ileri sürüyor. Sonra da bir takım kelime oyunlart ile Hz. Ebu Bekir nüshasımn resmî karakterini inkar ediyor ve nihayet Hz. Osman'm Kur'ân't istinsah ettirmeye karar verdiği sırada, muhtelif Islâm mekezlerinde büyük ihtilaftarın mevcut olmasını inıkan dahilinde görüyor yine bu sırada Kûfe'de Müslümanların bir kısmının Hz. Osman tarafından gönderilmiş olan yeni Mushaf' kabul ettiklerini, ancak büyük bir çoğunluğun ise Ibn Mes'ud'un mushafım benimsediklerini ve bu yüzden iki gruba ayrıldıklarınt ifade ediyor. Böylece, Jeffery'ye göre, $\mathrm{Hz}$. Osman tarafindan istinsah ettirilen Mushaf, bir çok rakip mushaf arasindan sadece bir tanesi olarak değil, ayn zamanda, eski mushaflara, hatta $\mathrm{Hz}$. Peygamber zamanindaki kuraâte muhalefet eden ve sonunda da derunî özelliklerinden ötürü değil de, Medine şehrinin prestiji sayesinde kendini kabul ettiren, yeni bir mushaf olarak karşımıza çıkıyor. Kuran-ı Kerim tarihinin bu sekilde ele alınması, fok ciddî hatalar doğuracă̆ından, meselenin yeniden ele alımıp aydınlı̆̆a kavuşturulması gerekir. "68

Arthur Jeffery'nin çalışmalarına, kıraâtler konusundaki derlemelerine ve bunların bir metin tenkidi için elverişli olup olamayacağı konusundaki tutumuna yönelik tepki gösterenlerden biri de Muhammad Chaudary'dir. Yazmış olduğu bir makalede Chaudary, Arthur Jeffery'nin çabalarına genel hatları ile şu tenkitleri yöneltmektedir: Jeffery'nin naklettiği kıraât farklılıklarının çoğu lehçe ve telaffuz farklılıkları olup bunlar $\mathrm{Hz}$. Peygamber'in başlangıçta okunmasına izin verdiği ve onayladığı farklılıklardır. Hatta yerine 'atta, sırât kelimesinin sat veya sin ile okunması, Fatiha suresindeki Ihdina yerine Erşidna kelimesinin, la yerine ğayri kelimelerinin okunması gibi. Chaudary bu itirazında son derece haklıdır zira

68. Draz Abdullah, Kur'ân'a Giriş, ç. S. Akdemir, Kitabiyat, Ank. 2000, s.39-40; Jeffery, 1957 yılında yayımladığı ve güncel Kur'ân çalışmalarının uzunca bir değerlendirmesini yaptığı "The Present Status of Quranic Studies" başlıklı makalesinde M. Draz'ın bu kitabından haberdar görünmektedir. Jeffery, Draz ile ilgili olarak onun Müslümanların kutsal kitabına yönelik her türlü batılı anlamda bilimsel yaklaşıma gücenip içerlediğini, kızdıgını belirtmektedir. Bkz. Jeffery. "The Present Status of Quranic Studies", Report on Current Research, Washington, Spring, 1957, s.5. 
Jeffery, bir makalesinde Fatiha suresinin şazz olan iki farklı varyantını nakletmektedir. Ancak sonunda kendisi bile bir yandan naklettiği bu varyantların asıl metinle mana olarak hiç bir farkının bulunmadığını belirtirken öte yandan da bu surenin önceleri şifahen korunup sonradan Kur'ân toplanırken sabitlendiğini belirterek bir takım kuşkulara yol açmaya çalışmaktadır ${ }^{69}$ Yine Chaudary'nin belirttiğine göre Jeffery, senedi zayıf da olsa muhtelif eserlerde nakledilen farkliliklara dayanarak $\mathrm{Hz}$. Osman metnine yönelik şüpheler yaratmakta tereddüt etmemesine karşın İslâm dünyasının icmaını görmezden gelmektedir. Onun aktardığı nakillerden bir kısmının sahih ve $\mathrm{Hz}$. Osman Mushafı öncesinde kullanılmakta olduğunu varsaysak da haberi vahidle ( $\mathrm{ahad}$ ) gelen bir rivayet veya metnin, tevatüren (mütevatir) nakledilen $\mathrm{Hz}$. Osman metnine tecih edilmesi sözkonusu olamaz.

Jeffery, Kur'ân'ın hıfz yolu ile naklini tamamen ihmal etmiş ve görmezden gelmiştir. Oysa Kur'ân $\mathrm{Hz}$. Peygamber'den başlamak üzere günümüze kadar hem kitâbî hem de şifâhî olarak nakledilegelmiştir. $\mathrm{Hz}$. Osman döneminde Medine metni rafa kaldırılmamış, İmam mushaf olarak korunmuş, diğer nüshalar büyük şehirlere gönderilmiştir. Asıl metne ve dağıtılan diğer mushaflara yönelik itirazı olan hafız sahabiler olsaydı daha baştan itiraz ederlerdi. Oysa ashab, Osman Mushafı'nın sahihliğini onaylamıştır.

Jeffery, İbn Mesud'un biraz tereddütten sonra mushafinı Osman'a teslim etmesini ve artık bundan sonra ona atfedilen bir kıraâtin bulunmadığını, dahası İbn Mesud'un Hz. Osman cem'inin Hz. Peygamber'e dayanmadığına dair bir ifadesi veya beyanı olmadığını görmezden gelmektedir. İbn Mesud'un kendi mushafını koruma arzusunu da anlayışla karşılamak gerekir; zira onun kendi alıştığı ve aşina olduğu metni koruma arzusu son derece doğal bir davranıştır.

Jeffery daha sonra gelen bir çok kelamcı, dilci ve gramercinin itibar/ nüfuz sağlamak maksadıyla kendilerinin icad ettikleri bir takım kıraâtleri ilk dönem otoritelerine dayandırdıklarını bilmesine ve hatta itiraf etmek zorunda kalmasına, dahası bir çok yerde naklettiği farklılıkların gramatik açıdan yanlış olduğunu belirtmesine rağmen ${ }^{70}$ tenkitli bir Kur'ân metnini oluşturma adına kıraât derlemesine yönelik ilgisini sürdürmüştür.

Jeffery, Hz. Ebu Bekir'in cem'ini tıpkı Richard Bell gibi şahsî bir olay olarak görmekte ve böylece İslâm ve Kur'ân hakkındaki önyargılı tutumunu gizlemekte başarısız kalmaktadır. Oysa Hz. Ebu Bekir o devirde fiilen devlet başkanıdır. Bu cem'in resmî bir işlem olduğunu da cemedilen Mushaf'

69. Jeffery. "A Variant Text of The Fatiha", $M W, 29(1939)$ s.162.

70. Jeffery, Materials, s. 15, 16. 
Ebu Bekir'in vefatından sonra ikinci halife Hz. Ömer'e geçmesi açıkça göstermektedir. Öyle olmasaydı bu Mushaf Hz. Ömer'e değil kızı Hz. Aişe'ye geçerdi. Hz. Ömer'den sonra Hz. Hafsa'ya geçmesinin nedeni ise kimin halife olacağının henüz belli olmamasıdır.

Jeffery, Bergstrasser ve talebesi Otto Pretzl'lin yaptığı çalışmalardan, Münih'teki Kur'ân Arşivi ve oradaki faaliyetlerden bahsetmesine karşın Pretzl'in ömrünün son dönemlerinde konuya yönelik ilgisizliğini ve Arşiv'in yayımladığı geçici raporda ortaya koyduğu sonuçları görmezden gelmekte ve bu konuya hiç bir çalışmasında değinmemektedir ki bu tutumun bilimsel objektivite ile bağdaşır tarafı yoktur. ${ }^{71}$

Mütevatir olarak nakledilen $\mathrm{Hz}$. Osman metni ile ilgili kuşkular ileri sürmesine rağmen kendisi şazz ve ahad haber ayrımı yapmadan bulduğu her şeyi kaydetmeye çalışmaktadır ki, bir yerde naklettiği bazı kıraâtlerin gramatik açıdan imkansız olduğunu itiraf etmek zorunda kalmıştır. ${ }^{72}$

Şunu da belirtmemiz gerekir ki İslâm dünyasında son dönemlerde yapılan çalışmalarda Kur'ân'ın daha $\mathrm{Hz}$. Peygamber hayattayken vahiy katipleri tarafından bütünüyle kaydedildiği, Hz. Ebu Bekir'in Zeyd b. Sabit'e yaptırdığı cem işleminin aslında vahiy katiplerine yazdırılan fakat dağınık vaziyette bulunan Kur'ân ayetlerini o anda mevcut olan daha düzgün bir malzemeye yazarak onları müracaat edilmesi kolay bir mecmua haline getirmekten başka bir şey olmadığı da vurgulanmaktadır. ${ }^{73}$

Yapılan bu çalışmalardan kıraât ve tefsir ilminde yararlanılması meselesine gelince bu hususun geçmişte yapılmadığını söyleyemeyiz. M. Draz'ın da dediği gibi İslâm uleması namazda okunma ve Mushaf metnine dahil edilme dışında bu farklı kıraâtlere her zaman ilgi duymuş, onlan tefsir eserlerinde kullanmış ve mümkün mertebe onlardan yararlanma yoluna gitmişlerdir. Buna en çarpıcı örnek büyük müfessir et-Taberî'nin Câmiu'l Beyan adlı eserinde kıraât konusuna verdiği önemdir. ${ }^{74}$ Aynı tutumun diğer Kur'an müfessirleri için de geçerli olduğunu söyleyebiliriz, nitekim Jeffery'nin kıraât derlemelerini yaptığı kaynaklar listesinde yer alan tefsire dair eseri bunu ispat için yeterlidir. Yine muhtelif kıraâtlerin ortaya

71. Chaudary. "Orientalism on Variant Readings of the Qur'an: The Case of Arthur Jeffery", s.179-181.

72. Jeffery, Materials, s.16.

73. Konuyla ilgili geniş bir değerlendirme için bkz. Derveze M. İzzet, el-Kur'ânu'l-Mecid, Matbaatu'l Asriyye, Lübnan, Trh, s.52-116; Akdemir, Cumhuriyet Dönemi Kur'ân Tercümeleri, Akid Yay, Ankara, 1989, s.12-24; "Kur’ân'ın Toplanması ve Kıraâti Mesclesi", (I. Kur'ân Sempozyumu içinde) Bilgi Vakf1, 1994, s.28.

74. Albayrak, Halis, "Taberí'nin Kıraâtleri Değerlendirme ve Tercih Yöntemi", AÜIFD. c. s.103-136 
konması konusunda Müslümanlar tarafından yapılan müstakil çalışmalar geçmişte olduğu gibi günümüzde de artarak devam etmektedir. ${ }^{75}$ Jeffery ve meslektaşlarının yayımlamayı arzu ettiği ve fakat başaramadığı Kur'an'ın tenkitli neşri konusundaki çabanın bir benzeri bizzat Müslüman araştırmacılar tarafından gerçekleştirilmiş ve asıl metnin kenarında belli başlı Kur'an kıraâtlerine de yer veren Kur'an nüshaları neşredilerek ilim dünyasının hizmetine sunulmuştur. ${ }^{76}$

Kıraâtler konusunda ortaya çıkan ve giderek artan çok sayıdaki bu kaynak malzemeden daha geniş çapta yararlanma, mütevatir kıraâtlerin özellikle de tefsir ilminde daha etkin bir şekilde kullanılması gerektiğine dair talepler günümüz araştırmacılarının yaptıkları çalışmalarda da dile getirilmektedir. Ülkemizde kıraâtler konusuna ilgi duyan bazı araştırmacılar farklı kıraâtlerden tefsir ilminde de yararlanılmasının gerekliliğine muhtelif çalışmalarında işaret etmektedirler. Örneğin özellikle kıraâtler konusunda yapmış olduğu çalışmaları ile dikkati çeken İ. Karaçam bu konudaki arzusunu şu cümlelerle dile getirmektedir:

"Tefsir çeşitleri arasında, bazı ilimlere ağıllık vermek suretiyle rivayet tefsirleri, dirayet tefsirleri, işari tefsirler.. gibi tefsirler kaleme alındı̆̆ı halde ktraât ă̆ırlıklı tefsire rastlayamadı̆̆ınızı söylemeliyiz. Ancak yeri geldiķ̧, kendisine ihtiyaç duyuldukça, kıraâtler bir malzeme olarak kullamlmıştır. Sıhhatleri konusunda gereken titizlik gösterilmediği için de garplı bazı müsteşrikler tarafindan Kur'ân Kerim'in tenkidine sebep olunmuştur. Kanaatimize göre Kur'ân-ı Kerim'in kuraât ă̆ırlıklt ve özellikle mütevatir kıraâtlere dayanan bir tefsiri yapılmalıdır. ${ }^{177}$

\section{Sonuç}

İsmail Cerrahoğlu, oryantalistlerin İslâmî ilimler alanında yaptıklanı çabaları değerlendirirken misyonerlik, müstemlekecilik ve siyaset gibi hususlarda bir fayda tevehhüm etmeksizin sırf ilim için çalışan oryantalistlere kolay rastlanamadığından yakınmaktadır. ${ }^{78}$ İncelemeye çalıştığımız Arthur Jeffery'nin Kur'ân ve kıraâtler konusuna dair yaklaşımları da, bize bu yakınmanın haklı olduğunu gösteren önemli örneklerden biridir. Cerrahoğlu,

75. Yalnızca bir kaç örnek için bkz. Abdulfcttah Abdulł̧anî, el-Budûru'z-zâhire fí'l-kıraâti'laşri'l-mütevâtire, Daru'1-Kitabi'l-Arabi, Beyrut, 1981; M. Salih Muhaysin, el-Muğnî $f$ i tevcîhi'l-kıraâti'l-aşri'l-mütevâtire, Daru'l-Cil, Beyrut, 1988; Mahmud Husañ. el-Kırấtu'l-a'şere mine's-şâtbiyye ve'd-dürre, Şirketu'ş-Şemerli, Kahire, t.y.; Muhammed Habeş, el-Kıraâtu'l-mütevâtira ve eseruha fi resmi'l-Kur'an, Darul-fikr, Dımeşk. 1999; M. Fehd Haruf, M. Kerim Racih, el-Müyesser fi'l-kiraâti'l-erba'a-aşer, Daru'l-Kelimi'tTayyib, Dımeşk, 2000.

76. Muhammed Kerim Racih, el-Kıra'âtu'l-mütevâtire, Daru'l-Muhacir, Medine, t.y.

77. Karaçam, İsmail, Kıraât Illminin Kur'ân Tefsirindeki Yeri ve Mütevâtir Kıraâtlerin Yoruın Farklılıklarına Etkisi, MÜIFVY, İst, 1996, s.222-223.

78. Cerrahoğlu, a.g.m., s.113,114. 
oryantalistlerin İslâm medeniyeti dışındaki diğer medeniyetlere karşı sevgi ve takdir hisleri beslerken İslâm'a karşı aynı usulü kullanmaktan kaçındıklarını vurgulamaktadır. Hayatı, bilimsel çalışmaları ve Kur'an ilimleri konusundaki temel görüşlerine yer vermeye çalıştığımız Arthur Jeffery, kıraâtler konusunu kullanarak Kur'ân'ın Müslümanlar nezdindeki otoritesi ile diğer din mensupları nezdindeki cazibesini zayıflatmaya çalışmış ancak istediği sonuçlara ulaşamamıştır.

Genelde oryantalistler özelde Arthur Jeffery'nin İslâmî ilimler alanında özellikle de Kur'ân hakkında önemli sayıdaki eseri tahkik ve neşrederek ilim dünyasına kazandırma çabaları inkar edilemez. Ancak tümünü bununla itham edemesek de çoğunun kullandıklanı malzemenin yorumunda objektif olamadıklarını, önyargılarından kurtulamadıklarını ve hemen her fırsatta bu dinin kutsal kitabının otoritesini ortadan kaldırmaya yönelik çabalardan geri durmadıklarını görmemek de imkansızdır. Dolayısıyla onlardan ve çalışmalarından bu gerçekleri dikkate alarak yararlanmaya çalışmak, onlarla bu esas çerçevesinde ilişki kurmak, eserlerinden yararlanırken temkinli olmak gerekmektedir. Öte yandan söz konusu önyargıları ve art niyetli değerlendirmeleri eleştirirken savunmacı ve duygusal bir tutumdan uzak durmak; aksine, muhataplarımızın niyet ve düşüncelerini derinliğine tahlil ederek hedeflerini açığa çıkarma yolu yeğlenmelidir.

Her şeye rağmen şunu da belirtmeliyiz ki, kıraât sorununun Müslüman ilim adamlan arasında tepkisel ve duygusal tutumlardan uzak bir şekilde tam bir ilmî ciddiyet içerisinde incelenerek değerlendirilmesi, bu bağlamda günümüzde sergilenmekte olduğunu memnuniyetle gözlemlediğimiz bilimsel çabaların daha da yoğunlaştırılarak sürdürülmesi kaçınılmaz bir gerekliliktir. 